IZA DP No. 4912

What Determines Family Structure?

David M. Blau

Wilbert van der Klaauw

April 2010 


\title{
What Determines Family Structure?
}

\author{
David M. Blau \\ Ohio State University \\ and IZA
}

\author{
Wilbert van der Klaauw \\ Federal Reserve Bank of New York
}
Discussion Paper No. 4912
April 2010

IZA

P.O. Box 7240

53072 Bonn

Germany

Phone: +49-228-3894-0

Fax: +49-228-3894-180

E-mail: iza@iza.org

\begin{abstract}
Any opinions expressed here are those of the author(s) and not those of IZA. Research published in this series may include views on policy, but the institute itself takes no institutional policy positions.

The Institute for the Study of Labor (IZA) in Bonn is a local and virtual international research center and a place of communication between science, politics and business. IZA is an independent nonprofit organization supported by Deutsche Post Foundation. The center is associated with the University of Bonn and offers a stimulating research environment through its international network, workshops and conferences, data service, project support, research visits and doctoral program. IZA engages in (i) original and internationally competitive research in all fields of labor economics, (ii) development of policy concepts, and (iii) dissemination of research results and concepts to the interested public.
\end{abstract}

IZA Discussion Papers often represent preliminary work and are circulated to encourage discussion. Citation of such a paper should account for its provisional character. A revised version may be available directly from the author. 
IZA Discussion Paper No. 4912

April 2010

\section{ABSTRACT}

\section{What Determines Family Structure?*}

We estimate the effects of policy and labor market variables on the fertility, union formation and dissolution, type of union (cohabiting versus married), and partner choices of the NLSY79 cohort of women. These demographic behaviors interact to determine the family structure experienced by the children of these women: living with the biological mother and the married or cohabiting biological father, a married or cohabiting step father, or no man. We find that the average wage rates available to men and women have substantial effects on family structure for children of black and Hispanic mothers, but not for whites. The tax treatment of children also affects family structure. Implementation of welfare reform and passage of unilateral divorce laws had much smaller effects on family structure for the children of this cohort of women, as did changes in welfare benefits. The estimates imply that observed changes from the 1970s to the 2000s in the policy and labor market variables considered here contributed to a reduction in the proportion of time spent living without a father by children of the NLSY79 cohort of women. This suggests that the observed increase in this non-traditional family structure in the U.S. in the last three decades was caused by other factors.

JEL Classification: J12

Keywords: family structure

Corresponding author:

David Blau

Department of Economics

Ohio State University

Arps Hall

1945 N. High St.

Columbus $\mathrm{OH}$ 43210-1172

USA

E-mail: blau.12@osu.edu

\footnotetext{
* Financial support from NICHD grant HD45587 is gratefully acknowledged. Thanks to Karin Gleiter for expert programming. We appreciate helpful comments and suggestions from Audrey Light, Bruce Weinberg, and seminar and conference participants at the 2007 Population Association of America meetings, Brown University, Yale University, Ohio State University, the University of Virginia, the University of Washington, UQAM, and the Brookings Institution. The authors alone are responsible for the contents. The views expressed are those of the authors and do not necessarily reflect those of the Federal Reserve Bank of New York.
} 


\section{Introduction}

The most prevalent type of family structure in which children in the U.S. are raised today is the traditional one, in which both biological parents are present in the home and married. But in the past 30 to 40 years it has become increasingly common for children to experience alternative family structures, such as living with the mother with no father present, the mother and a step-father, and cohabiting parents. Children who grow up in a family with married biological parents have better education, employment, marriage, childbearing, and psychological outcomes on average than their counterparts who spend substantial parts of childhood living in alternative family structures ${ }^{1}$. These differences are generally quite large, and dwarf the effects of income and maternal employment. The evidence suggests that at least part of the association between family structure and child outcomes is causal. There is much still to be learned about the consequences of growing up in alternative family structures, but there is a consensus that family structure has important consequences for children.

In contrast, there is much less known about the determinants of family structure. The proximate determinants of family structure are well-studied demographic behaviors: union formation and dissolution, transition from cohabitation to marriage, and fertility, both in and outside of unions. But the implications of adult demographic behaviors for the family structure experiences of children depend crucially on interactions among these behaviors. For example, the impact of being born out of wedlock is likely to depend on whether the mother and biological

${ }^{1}$ See for example Aughinbaugh, Pierret, and Rothstein (2005), Chase-Lansdale, Cherlin, and Kiernan (1995), Gennetian (2005), Ginther and Pollak (2004), Hetherington and StanleyHagan (1999), Hofferth (2006), Lang and Zagorsky (2001), McLanahan and Sandefur (1994), and Sigle-Rushton, Hobcroft, and Kiernan (2005). 
father subsequently marry or cohabit, and if so, how soon after the birth of the child. The impact on a child of the dissolution of a union may depend on whether the man in the union was the child's biological father or a step father, and on the duration of the union.

Economic theories of family formation and dissolution suggest a number of observable factors that affect the demographic behaviors that determine family structure. ${ }^{2}$ These include the wage rates available to men and women; the tax and transfer incentives to cohabit, marry, and bear children; the legal environment governing divorce and child support provided by absent parents; and the state of the marriage market. Many studies have examined the effects of these factors on the family structure experiences of children, but most have taken a relatively narrow approach. For example, a typical study examines the impact of changes over time in one or two determinants of family structure, without considering the implications of simultaneous changes in other factors. Most studies examine only one or two of the key demographic behaviors that determine the family structure experienced by children. For example, one study might focus only on entry to cohabitation and marriage, while another study examines childbearing while single, and a third study analyzes marital dissolution.

In this paper, we propose a new approach to analyzing the determinants of the family structure experiences of children and the causes of changes over time in family structure. Our approach has four distinguishing features. First, we jointly model union formation, union dissolution, and childbearing decisions. Previous analyses have integrated some of these behaviors in a single model, but none have integrated the full range of behaviors needed for a

${ }^{2}$ See Akerlof, Katz, and Yellin (1996), Becker (1981), Neal (2004), and Willis (1999). Other theories emphasize less easily observed factors: see Ellwood and Jencks (2004). 
thorough analysis of family structure. A major feature of change in recent years has been delinking of marriage and childbearing decisions. Hence it is crucial to recognize that marriage and childbearing are in fact distinct decisions, and that treating "single parenthood" as one decision rather than the consequence of related but distinct union and childbearing decisions misses key elements of changes in behavior (Ellwood and Jencks, 2004). Furthermore, a substantial part of the increase in single parenthood in the last three decades can be accounted for by a rise in the presence of children with cohabiting parents (Bumpass and Lu, 2000), but child outcomes are worse in cohabitation than marriage, other things equal (Deleire and Kalil, 2002; Hofferth, 2006; Thomson et al., 1994). Thus for the purpose of analyzing family structure it is important to allow for a three-way classification of unions.

Second, we analyze the major hypothesized driving forces behind family structure changes jointly, including changes in public assistance policy, divorce laws, tax laws, and wage rates. By considering the main driving forces jointly rather than focusing on one or two in isolation from others, as in much of the literature, we provide a more robust accounting of the factors driving family structure changes.

Third, the analysis is dynamic, and distinguishes between the short run timing effects and the long run "avoidance" effects of key driving forces. In some cases, the major changes have been in the timing of childbearing and marriage, while for others the most important aspect of change has been more radical, namely avoiding marriage or childbearing altogether (Ellwood and Jencks, 2004). Most empirical analyses do not come to grips with this issue: they are either explicitly focused on outcomes at certain ages (e.g., marriage by age 24 , or non-marital childbearing by age 19), or they look at marital and childbearing transitions over short periods. 
Exceptions to this generalization include Keane and Wolpin (2006), Seitz (2009), Swann (2005), Tartari (2006), and van der Klaauw (1996). These papers structurally estimate dynamic economic models of marriage and employment (and in some cases fertility and welfare participation). With the exception of Tartari, these papers do not focus on family structure from the perspective of children, so they do not model cohabitation or the identity of male partners, which are important features of our model.

Fourth, and perhaps most important, we model the behavior of the adults who make union and childbearing decisions, but we derive from the model the consequences of these decisions for the family structure experienced by children. Thus we model choices that determine the identity of men who are in the mother's household from the perspective of children: step or biological father. This approach is unique in the literature on family structure changes. This is important because there is considerable evidence that living with the biological father is associated with better child outcomes compared to living with a stepfather, other things equal (e.g. Hofferth, 2006; McLanahan and Sandefur, 1994).

We use data from the 1979 cohort of the National Longitudinal Survey of Youth (NLSY79) to analyze the fertility, union formation, union dissolution, type of union (cohabiting versus married), and father identity (biological versus step) choices of women born from 1957 to1964. We follow these women from the 1970s, as they enter adolescence, through 2004, when they are in their 40s. We analyze the effects of state-year-specific policy and labor market variables over a three decade period, allowing the effects of these variables to differ for whites, blacks, and Hispanics, in recognition of the important differences in levels and trends for these groups. We exploit both cross-state variation and within-state variation over time to identify the 
effects of these contextual variables, and we examine the sensitivity of the results to the source of variation. A limitation of using a narrow range of birth cohorts is that we do not have independent variation in age and calendar time. For example, welfare reform occurred in the 1990s, when the NLSY79 cohort was well past the teenage years, so our approach cannot provide a credible estimate of the impact of welfare reform on the behavior of teenagers. But the richness and long duration of the NLSY79 provide information that is not available from other sources.

The econometric model we specify can be interpreted as an approximation to the decision rules implied by a dynamic economic model that fully specifies preferences, the budget constraint, and the expectations formation process. While computationally less demanding, the non-structural approach cannot give a precise interpretation to the parameters: they are combinations of parameters describing preferences, budget constraints and expectations. In our analysis we do not condition on other determinants, such as education, employment, child support, and welfare enrollment, that may be endogenous to the key demographic behaviors modelled here. Structural estimation of a fully specified economic model of family structure that would also include these additional determinants as chioce variables, is an important task for future research. ${ }^{3}$

The results indicate that the wage rates available to men and women have substantial effects on family structure for children of black and Hispanic mothers, but not for whites. A

${ }^{3}$ This non-structural approach is in the tradition of the "heterogeneity versus state dependence" literature (Heckman,1981), in which the cause of state dependence and other sources of dynamics are not explicitly modeled, but a rich dynamic specification can be estimated. Our specification, described below, includes measures of union duration, duration single, ages of the oldest and youngest children, the cumulative number of cohabitations, and other variables determined by previous choices. 
higher female wage rate increases the proportion of childhood spent living with no father, and reduces time spent living with the married biological father. A higher male wage rate decreases the proportion of childhood spent living with no father. For Hispanics, this is accompanied by an increase in time spent with the married biological father. For blacks there is an increase in cohabitation but not in marriage, and time spent in cohabitation increases by about the same proportion for the biological and step fathers. These effects are all consistent with standard economic models of the family. Changes in tax rates also affected family structure, while the effects of welfare benefits, welfare reform, and unilateral divorce laws are estimated to have had small effects. We use longitudinal data on a narrow range of birth cohorts, so it is difficult to make credible inferences from our estimates about the causes of cohort trends in family structure. Nevertheless, we use our model to simulate the effects of observed changes in the contextual variables from the 1970s to the 2000s, compared to the counterfactual of no change in these variables since the 1970s. The results indicate that the observed changes in policy and labor market variables over this period should have caused an increase in the proportion of childhood lived with the biological father and a decline in time spent with no father. Since the observed trends in family structure were in the opposite direction, we conclude that trends in wages and the policy variables cannot explain the trend away from traditional family structure.

We provide background and a brief review of previous findings in Section 2. Section 3 specifies the model and econometric approach. Section 4 describes the data. Section 5 presents the main results. Alternative specifications are discussed in section 6, and section 7 concludes.

\section{Background and Previous Findings}


The changes in family structure that are of interest here have been the result of a decline in marriage, increases in divorce and cohabitation, and an increase in childbearing outside of marriage. These changes are well-known and have been discussed extensively elsewhere (e.g. Bumpass and Lu, 2000; Bumpass, Sweet, and Cherlin, 1991; Cherlin, 1999; Fields and Casper, 2001; Martin et al., 2002; Stevenson and Wolfers, 2007). Here, we discuss their consequences for the family structure experiences of children, and briefly summarize previous findings on the causes of the changes.

Kreider (2008) summarizes recent family structure patterns of children using data from the Survey of Income and Program Participation (SIPP). In 2004, 58\% of children under the age of 18 were living with their married biological parents. Another 3\% were living with their cohabiting biological parents. Eight percent of children were living with one biological parent and one step or adoptive parent (in $80 \%$ of these cases the biological parent was the mother). $26 \%$ were living with one parent only (in $88 \%$ of these cases, the parent was the mother). Finally, $4 \%$ were living with neither parent. For most of the $20^{\text {th }}$ century up to 1970 , the percentage of children living in a two-parent family remained stable at 83-85\%. Between 1970 and 1990 the percentage in two parent families fell from 85 to $73 \%$ and the percentage in one parent families rose from 13 to $25 \%$, with little further change since 1990 . Family structure patterns and their changes vary substantially by race and, to a lesser extent, by ethnicity. In 2004, $67 \%$ of nonHispanic white children lived with both biological parents, compared to $31 \%$ of non-Hispanic black children, and $61 \%$ of Hispanic children (Kreider, 2008). ${ }^{4}$

Economic theories of the determinants of union formation, union dissolution, and

${ }^{4}$ Non-Hispanic will be implicit henceforth when referring to whites and blacks. 
childbearing behavior emphasize the role of the wage rates available to men and women; the tax treatment of marriage and children; the generosity and terms of public assistance to low income families with children; and the legal environment governing divorce ${ }^{5}$. We briefly discuss findings from the literature on each of these factors.

Wage rates. Becker's (1981) theory of marriage implies that the difference in potential wage rates between men and women affects the gains from specialization within marriage. The higher a woman's wage rate, the greater is the opportunity cost of staying home and raising children. The higher a potential husband's wage rate relative to the woman's wage rate, the greater is the incentive to marry in order to realize gains from specialization within marriage. A number of studies have found a negative effect of male wages and a positive effect of female wages on the prevalence of female headship. However, trends in wages do not contribute much to explaining the trend in single headship during the 1970s to 1990 s. $^{6}$ The effect of wage rates on fertility has also been studied; see Francesconi (2002) and references cited therein.

Taxes. It has been argued that expansion of the Earned Income Tax Credit (EITC) in the

\footnotetext{
${ }^{5}$ Many studies have examined the impact of abortion legalization and the availability of oral contraceptives on demographic behavior. We do not focus on these factors because both the legalization of abortion and the diffusion of easy access to oral contraceptives were completed by the early 1970s, before the women in our sample began childbearing and union formation. Other studies have analyzed the effects of marriage markets (i.e. the sex ratio) and the legal environment governing enforcement of child support obligations. In an earlier version of the paper, we reported estimates of a specification that included measures of the sex ratio and child support enforcement. The effects of these variables were generally small and insignificantly different from zero. We dropped them from the model in order to focus on the contextual variables that appear to be more important.

${ }^{6}$ See, for example, Blau, Kahn, and Waldfogel (2000), Fitzgerald and Ribar (2004), Bitler et al. (2004), and Moffitt (2001). Other features of the labor market in addition to wages may affect demographic behavior as well. We investigated the effects of the unemployment rate, but dropped it from the model after finding no evidence of any effects on the behaviors of interest.
} 
1980s and 1990s caused an increase in the marriage tax penalty (Hotz and Scholz, 2003).

However, there is little empirical evidence that the EITC has influenced marriage decisions. ${ }^{7}$

Welfare. Moffitt (1998) reviewed the large literature on the effect of welfare benefits on family behavior, and concludes that there is evidence of a positive association between welfare benefits and female headship. However, the magnitude and precision of the estimated effect are rather sensitive to specification. Furthermore, the trend in real welfare benefits in the 1980s and 1990s was downward, which should have led to a decline in female headship rather than the increase that was observed. Some recent studies have found more consistent evidence of a positive association between welfare benefits and female headship among disadvantaged young women, for whom welfare is likely to be a relevant option (Rosenzweig 1999; Foster and Hoffman, 2001; Hoffman and Foster, 2000). Blau, Kahn, and Waldfogel (2004) find no evidence that welfare benefits affect the likelihood that a young woman is a single mother. Light and Omori (2006) find that an increase in welfare benefits causes a reduction in transitions into marriage and an increase in transitions to cohabitation. They also report that an increase in the welfare benefit increases divorce for black women, but not for other groups.

A recent literature examines the impact on family structure of welfare reform in the late 1980s to the mid 1990s. The majority of studies find that welfare reform caused an increase in marriage and a decrease in divorce (e.g. Acs and Nelson, 2004; Bitler et al., 2006; Gennetian and Miller, 2004). However, social experiments undertaken as part of welfare reform show no

${ }^{7}$ See Dickert-Conlin and Houser (1998) and Ellwood (2000). There is no evidence on whether the EITC has influenced fertility. Other features of the tax code that affect marriage and childbearing incentives have also been analyzed, with results generally suggesting small effects in the expected direction (see Alm and Whittington, 2003). 
consistent impact on union formation in the welfare population (Harknett and Gennetian, 2003), and there is some evidence that welfare reform actually caused a decrease in marriage (Bitler et al. 2004; Kaestner et al., 2003). Fitzgerald and Ribar (2004) find no significant impact of welfare reform on female headship.

Divorce laws. Many studies have analyzed the impact of enactment of unilateral divorce laws on the divorce rate and related outcomes. Peters (1986) finds no impact, but Friedberg (1998), Gruber (2004) and others find a positive association between unilateral divorce law and the frequency of divorce. Wolfers (2006) reconciles these differences by showing that there is a positive short run impact of enactment of unilateral divorce but apparently no long run impact. This finding suggests the importance of dynamic considerations. Alesina and Giuliano (2006) find evidence that unilateral divorce reduces out of wedlock fertility, with no impact on marital fertility. They interpret this as indicating that when it is easier to escape marriage, women who plan to have a child are more willing to have the child within marriage.

\section{Model}

Our goal is to understand the family structure experiences of children who reside with their biological mother. ${ }^{8}$ The family structures of interest are living with the biological mother and (1) the married biological father, (2) the cohabiting biological father, (3) a married step father, (4) a cohabiting step father, and (5) no man. We assume that women become at risk of

${ }^{8}$ The NLSY has little information on children who do not live with the biological mother. Also, we do not distinguish living arrangements by the presence of grandparents or other nonparental adults because the model would have to be much more complex in order to do so. See Bitler et al. (2006) and DeLeire and Kalil (2002) for analyses of the presence of grandparents. 
entering a union and conceiving a child at age 12. A "union" refers to a co-residential romantic relationship, which may be a marriage or a cohabitation. We use a discrete time framework in which the unit of time is a month. In a given month $(t)$, woman $i$ 's situation is characterized by a set of fixed characteristics $X_{i}$ such as her race, ethnicity, and year of birth; the outcomes of previous childbearing and union formation and dissolution decisions, $Y_{i t}$, such as the number of children born and their ages, current marital and cohabitation status, and marital and cohabitation history; and a set of policy, labor market, and other aggregate variables $Z_{i j t}$, some of which may be choice-specific ( $j$ is the indicator for choices, defined below). We do not model schooling and employment decisions, and, as noted in the introduction, we do not condition on education and employment decisions. We also do not model migration behavior, but we do condition on the woman's state of residence.

Each period, a woman faces a set of childbearing and union options, from which she can choose one. We assume that at most one alternative can be selected from the choice set in a given month. The set of alternatives available to a woman in a given period depends on her previous choices. For example, if she is currently married, then the option of entering a marriage or cohabitation is not available. If she is currently pregnant, then conceiving a child is not an option. ${ }^{9}$ We assume that if she is in a cohabitation, then the only man she can marry in the current month is her partner. We also assume that if she is currently in a union, the only man with whom she can conceive a child is her current spouse or partner. Let $A\left(Y_{i t}\right)$ denote the set of alternatives

${ }^{9} \mathrm{We}$ consider only conceptions that lead to a live birth. Conception is treated as a choice but the birth is treated as a censoring event that ends the current pregnancy. Thus the duration of pregnancy and the decision to terminate a pregnancy are not treated as choices. Twin births are treated as an exogenous random event. 
available to a woman in period $t$, given her current state $Y_{i t}$. The alternatives are specified below. The value to a woman of choosing alternative $j$ is specified as

$$
V_{i j t}^{*}=\beta_{1 \mathrm{j}} X_{i}+\beta_{2 \mathrm{j}} Y_{i t}+\beta_{3 \mathrm{j}} Z_{i j t}+\beta_{4 \mathrm{j}} X_{i} Z_{i j t}+\beta_{5 \mathrm{j}} \mu_{\mathrm{i}}+\varepsilon_{i j t}, \quad j \in A\left(Y_{i t}\right)
$$

where $\mu_{\mathrm{i}}$ is a permanent unobserved woman-specific effect, $\beta_{5 \mathrm{j}}$ is an alternative-specific factor loading, and $\varepsilon_{i j t}$ is an $i i d$ shock. The inclusion of $\mu_{\mathrm{i}}$ captures persistence in unobserved factors, such as preferences, partner characteristics, and the state of the marriage market. The interaction between $X_{i}$ and $Z_{i t}$ allows policy and labor variables effects to differ by race/ethnicity.

We do not specify an explicit theory of choice behavior, but equation (1) is consistent with choice-theoretic approaches proposed by Becker (1981) and others. It is useful to think of (1) as an approximation to the value function associated with a given alternative. ${ }^{10}$ But the parameters do not have explicit choice-theoretic interpretations, as they capture both the response to current incentives and expectations about the future evolution of the key driving forces.

If woman $i$ chooses the alternative with the highest value in month $t$, and if $\varepsilon_{i j t}$ follows the Type I Extreme Value Distribution, then conditional on $\mu$ the probability that she makes choice $j$, $P_{i j t}$, has the multinomial logit form:

$$
P_{i j t}=\exp \left\{V_{i j t}\right\} / \sum_{k \in A\left(Y_{i t}\right)} \exp \left\{V_{i k t}\right\}
$$

where $V_{i j t}=V_{i j t}{ }^{*}-\varepsilon_{i j t}$. The conditional likelihood function contribution for woman $i$ is formed as the product, over the months for which she is observed, of probabilities for her observed choices, conditional on $\mu$. The unconditional likelihood contribution is the integral of the conditional likelihood over the distribution of $\mu$. The latter is treated as a discrete random factor with a twopoint distribution. The model is thus a discrete-time multi-state competing risks model of

\footnotetext{
${ }^{10}$ It is not a reduced form, as it contains variables $\left(Y_{i t}\right)$ determined by past choices.
} 
childbearing, union formation and dissolution, and "father identity." The model does not suffer from the usual Independence of Irrelevant Alternatives property of the multinomial logit model because the $\beta_{5 \mathrm{j}}$ parameters allow the disturbances to be correlated, although in a restricted manner (8 parameters determine the covariances among the disturbances). The model is estimated by maximum likelihood.

The full set of alternatives, not all of which are available in a given month, is

0. Do nothing

1. Conceive a child with the current man

2. Conceive a child with a new man

3. End the current union and become single

4. Enter a cohabiting union with the current man

5. Enter a cohabiting union with a new man

6. Marry the current man

7. Marry a new man

A new man is defined as a man who is not the father of any of a woman's children and with whom she has never lived. The current man is her partner or spouse if she is currently in a union. If she is not in a union, the current man is the father of her most recent child conceived since the end of her last union, if any, or since she began conceiving children if she has never been in a union. If she is not in a union and has not given birth to any children since the end of the previous union (or ever, if she has never been in a union), then there is no current man, and alternatives $1,3,4$, and 6 are not available. If she is currently in a union or pregnant, then as indicated above we assume that only the current man is relevant: she can conceive a child or 
enter a union only with the current man, so alternatives 2,5 , and 7 are not available.

Distinguishing between a new man and the current man is important because the choice between the two determines which of a woman's children will reside with, or be at risk of residing with, the biological father, and which with a step father. This important distinction has rarely been made in analyses of family formation behavior (see Graefe and Lichter, 1999, for an exception). We impose one key assumption in order to make it feasible to model the choice between a new man and the current man. If a woman ends a union with the current man or if she has a child with a new man, then she is not at risk of conceiving a child or entering a union again with the former current man. With this assumption, there is at most one current man.

The model is quite rich and flexible. It allows for observed and unobserved heterogeneity, state dependence, duration dependence, and other forms of history dependence. The effects of policy and labor market conditions are allowed to vary by race and ethnicity. Geographic and time effects are included in order to allow for unobserved heterogeneity across states and over time. In practice, the specification is restricted in various ways described below, in order to avoid an excessive number of parameters. But even after imposing restrictions, the model allows substantial flexibility in the effects of contextual variables on the family structure experiences of children. These effects are derived from simulations of the model, as described below.

\section{Data}

A. NLSY79

The NLSY79 began in 1979 with a sample of young men and women who were born between 1957 and 1964. They were interviewed annually from 1979 to1994 and biennially since 
1994. We use prospective data on female respondents through the 2004 interview, along with retrospective reports from the first interview about pre-1979 marriage and fertility behavior. We use the representative cross-section sample and the supplementary over-samples of blacks and Hispanics. Here we briefly describe measurement of the key variables; more details are available in Blau and van der Klaauw (2008).

In 1979, when the sample women were between the ages of 14 and 22, the survey collected information on the beginning and ending dates (to the nearest month) of up to two marriages. In subsequent waves, information has been collected on up to three changes in marital status since the previous interview. We treat the date of separation as the date of the end of a marriage, since the issue of interest is the presence of a man in the mother's household. However, there are many temporary separations that are followed by reuniting. Modeling the process that determines whether a couple reunites after a separation would make an already rich analysis excessively complicated. Thus, we ignore temporary separations if the duration of the separation was less than or equal to two years. Cases in which a temporary separation lasted more than two years are censored at the date of separation and no information beyond the separation date is used in the analysis. ${ }^{11}$

The survey has collected information on cohabitation in several different ways, including snapshots of cohabitations in progress at each interview date; the starting date of cohabitations that were in progress at the interview date, beginning with the 1990 interview; the starting date of

\footnotetext{
${ }^{11}$ There is one exception to this rule: if a woman never had any children prior to the end of a temporary separation that exceeded two years, her record is not censored, since there are no children affected by the separation. $19 \%$ of the approximately 1,700 separations were temporary. The median duration of a temporary separation was 17 months, and $60 \%$ were shorter than two years.
} 
cohabitations that turned into marriages that were in progress at the interview date, also

beginning with the 1990 interview; and both the beginning and ending date of cohabitations that did not turn into marriages, beginning with the 2002 interview. Cohabitations that began and ended before the 1979 interview, or that began and ended between interviews before 1990 are missed. ${ }^{12}$ We combined information from the various reports to form as complete a cohabitation history as possible. The cohabitation and marriage histories were combined to form a complete union history. We performed extensive consistency checks on the union history, and examined and corrected many anomalous cases by hand (the resulting code is available on request). Cases in which exact starting or ending dates of unions are uncertain are retained, and the likelihood function is modified to integrate over all feasible dates. See Appendix A for details. However, we dropped 401 cases with either unresolvable inconsistencies in the timing of unions or patterns that violate the assumptions of the model. ${ }^{13}$

The month and year of birth is reported for each child, and beginning in 1984 women

\footnotetext{
${ }^{12}$ Sixty percent of observed cohabitations that did not turn into marriages had a beginning date that was not known to the nearest month, and $95 \%$ had an ending date that was not known to the nearest month. Forty percent of cohabitations that turned into marriages had a beginning date that was not known to the nearest month. Bumpass and Lu (2000) use retrospective data and report that almost $50 \%$ of women in the NLSY79 cohort had ever cohabited by the time they were in their 30s. Our estimate from the NLSY79 is 40\%, so clearly we are undercounting cohabitations. The cohabitations most likely to be missed in the NLSY79 are short, and children are relatively unlikely to be born during a short cohabitation. So missed cohabitations are less important for purposes of studying family structure experienced by children than for studying the incidence of cohabitation.

${ }^{13}$ These include 114 cases in which a woman dissolved a union with a man and subsequently reentered a union with the man, 68 cases in which a woman had a child with one man, then had a child with a second man, and finally had another child with the first man, and 65 cases in which two or more demographic events occurred in the same month. Many of these cases may be a result of errors in identifying men. We were able to correct such errors in some cases but not in these cases.
} 
were asked the month in which each pregnancy began. We use this information to identify the month of conception. If the month of conception is missing, we assume the conception occurred nine months prior to the birth.

Beginning with the 1984 interview, the mother is asked for each of her co-resident biological children whether the child's biological father is present in the household. Thus, when a woman lives with a man before or during the conception and birth, identifying fathers is straightforward. The more difficult cases are those in which a woman who has given birth to a child since the end of her previous union (or since she began bearing children, if she has never been in a union) conceives and bears another child while single. In such cases, we need to determine whether the father of the new child was the same man who fathered her previous child, but we can do this only if she subsequently enters a union (and is interviewed while the union is still in progress). If she never enters a union following the birth of a child, we cannot determine whether the father of that child was the current man or a new man. Of the 1,086 cases in which a child was conceived and born to a single woman who had given birth to a child since the end of her previous union, we are able to identify whether the father is the current man or a new man in $35 \%$ of the cases. Rather than discard the remaining cases, we modify the likelihood function to account for both of the possibilities, weighted by the probability (from equation 2) that the father was the current man or a new man. This modification is described in Appendix A. ${ }^{14}$ This

\footnotetext{
${ }^{14}$ In some cases the sequence in which events occurred is uncertain, as a result of lack of exact information on start or end dates of unions. For example, if a man moved into the woman's household between interviews and a child was born between the same interviews, we cannot always determine whether the man moved in before or after the child was born. We modified the likelihood function to account for the alternative feasible sequences in which the events occurred. This is also described in Appendix A. Missing information on the identity of men and uncertainty about the sequence of events occurred for $12 \%$ of children of white mothers, $48 \%$ of children of
} 
approach will produce consistent parameter estimates if the data are missing at random conditional on the observables and the permanent unobserved factor $(\mu)$.

At each interview date we can determine from the household roster whether a given child is present in the mother's household. Modeling whether a child lives with the biological mother would be interesting, but is beyond the scope of this paper. The processes that determine this are thus treated as exogenous censoring processes, and the number of children present in the mother's household is adjusted when a child moves in or out. Cases in which a child is away at school or living part-time with the mother are treated as if the child is living with the mother. The death of a child is treated as a censoring event, and children's records are censored at age 18.

After dropping cases with incomplete data or unresolved inconsistencies, we are left with a sample of 4,476 women out of 4,926 eligible for inclusion. ${ }^{15}$ Descriptive statistics on the analysis sample are displayed in Table 1, separately for whites, blacks, and Hispanics. The first panel summarizes outcomes of the demographic processes modeled here, as of the last interview. The sample women were aged about 40 on average as of the last observation. ${ }^{16}$ White women

black mothers, and $25 \%$ of children of Hispanic mothers. This pattern reflects the relatively high incidence of births while single among black women and cohabitations among Hispanic women. We compared sample means of the variables reported below in Table 1 for the full sample, weighting by the inverse of the number of sequences, with corresponding statistics on the subsample with no missing information. The two samples are very similar for whites, with the largest difference in means equal to 0.03 . For Hispanics the largest difference is 0.06 , and most are equal to 0.01 or 0.02 . For blacks, the largest difference is 0.09 , with most of the differences in the range of 0.05 to 0.06 .

${ }^{15}$ The omitted cases include the 401 cases mentioned above with inconsistent marriage and cohabitation histories, and another 32 cases with problematic data on children and fathers. Another 17 cases are lost as a result of missing or inadequate data on contextual variables.

${ }^{16}$ Women who attrited from the sample are included in the analysis, with attrition treated as an exogenous censoring event. The last interview was in 2004 for $72 \%$ of women. Women 
had given birth to an average of 1.71 children, and $21 \%$ had not given birth to any children.

Black and Hispanic women had about 0.2 to 0.3 more births on average than whites. Eighty nine percent of white women had ever been married, compared to $62 \%$ of black women and $82 \%$ of Hispanic women. White women were also somewhat more likely to have ever cohabited.

The lower panel of Table 1 summarizes the incidence of the family structure outcomes experienced by the 8,027 children born to the sample women as of their last interview. The children were aged 13-14 on average at the time of the last observation (after truncating at age 18; without truncating, they were 14-16). Thirty one percent of children of white mothers had ever lived without a father figure present, compared to $76 \%$ of the children of black mothers and $45 \%$ of the children of Hispanic mothers. Most children of white and Hispanic mothers lived with both biological parents at some point in their childhood (94\% and 85\%, respectively), compared to $52 \%$ of the children of black mothers. Children of black mothers were more likely to live with a stepfather and/or a cohabiting father compared to children of white and Hispanic mothers, but these differences are smaller.

A concern with using a long panel for a study of family structure is that attrition and immigration could make the sample increasingly unrepresentative over time. Most studies of family structure use a time series of cross sections, and do not face this problem, although they cannot study individual-level dynamics with such data. To examine this issue we compared summary statistics for the NLSY79 cohort in the NLSY79 data and the March Current Population Survey (CPS), for two years, 1995 and 2004. 1995 is the first CPS survey year in which cohabitation is well-measured, and 2004 is the last year of data in our NLSY sample. The who were interviewed in 2004 were between the ages of 39 and 47. 
results are shown in Appendix Table A-1. Panel A shows close agreement on union status between the two data sources for whites in 1995, with a bit more disparity by 2004. For example, the percent single in 1995 was 21.9 in the NLSY and 20.2 in the CPS, while in 2004 the figures were 22.3 and 18.3, respectively. The NLSY estimate of percent single for blacks differs by 4 percentage points from the CPS, increasing to 8 percentage points by 2004. The NLSY-CPS difference in percent single for Hispanics is 7 percentage points in 1995 and 6 percentage points in 2004. The percent of Hispanic women cohabiting in 1995 is 8.1 in the NLSY versus 2.1 in the CPS, although the gap is only one percentage point in 2004. The largest disparity for Hispanics is 14 percentage points for percent married in 1995 , shrinking to 7.5 percentage points in 2004 . It is plausible that the largest disparity would be for Hispanics, since the bulk of immigrants in the last 30 years were Hispanic. Panel B shows that mean years of education for whites and blacks are very close in the NLSY and CPS, but over one year higher in the NLSY compared to the CPS for Hispanics. This pattern is likely due to lower education among recent Hispanic immigrants compared to Hispanics present in the U.S. in 1979.

Panels $\mathrm{C}$ and $\mathrm{D}$ show close correspondence in the number of children present in the woman's home by age group, and the fraction of women with no children in the home. Panel E shows that the distribution of children by the mother's union status is quite a bit closer between the NLSY and CPS than is the distribution of women by union status. The CPS does not identify biological versus step children, so this comparison cannot be made. Finally, Panel F shows that the percent of children with no father present is remarkably close in the two data sets. Overall, the NLSY79 sample has not been compromised by attrition, but is increasingly unrepresentative of Hispanics (see MaCurdy et al., 1998, for an extensive analysis of attrition in the NLSY79). 


\section{B. Contextual Data}

The geo-coded version of the NLSY79 provides the state of residence at each survey date, and at the time of the woman's birth and when she was age 14. We collected data from a variety of sources on welfare benefits, welfare reform, divorce laws, tax rates, and labor market conditions, and merged them with the NLSY79 data by state and year. Here we briefly describe the key measures; Appendix B provides details, and describes how state of residence was assigned for non-survey years.

The real (year 2000 dollars) Aid to Families with Dependent Children (AFDC) or Temporary Assistance for Needy Families (TANF) plus Food Stamp benefit for a family of four (single mother with three children under 18) with no other income is used as a measure of the welfare benefit. The average welfare benefit declined in real terms over much of the sample period, with a couple of episodes of relative stability (see Figure 1A). The month and year of implementation of major welfare waivers and the TANF program for each state are used to characterize welfare reform. The welfare reform variable indicates the presence of any major change in welfare rules authorized by a waiver or TANF. ${ }^{17}$

The month and year of enactment of unilateral divorce laws were taken from Gruber (2004), which is an update of Friedberg's (1998) data. Unilateral divorce means that mutual consent for a divorce is not required. Most such laws were enacted in the 1970s, but there were occasional later cases in which states passed a unilateral divorce law (Figure 1C).

${ }^{17}$ TANF was implemented by all states, while not all states requested a welfare waiver. TANF incorporated many of the rule changes implemented by various states as part of their waivers, including time limits and welfare-to-work (workfare, learnfare) programs. TANF was implemented by states between 1996 and 1998. See Figure 1B for the aggregate timing pattern. 
The TAXSIM program provided by the National Bureau of Economic Research (NBER) was used to compute the average tax rate for alternative filing statuses and numbers of children. The program accounts for all major features of the tax code, including the EITC and (beginning in 1977) state taxes. Rather than conditioning on the woman's observed income, we specify an arbitrary real income level that is used for all women in all years. This ensures that the only variation in the tax rate used in the model is due to tax code variation over time and across states. In the results reported here, we used the real equivalent of the year 2000 poverty line for a family of three. We estimated an alternative specification using the real equivalent of year 2000 median family income, and found similar results. The average tax rate is a better characterization than the marginal tax rate for the implications of alternative discrete marriage and childbearing choices. The tax rate is treated as a choice-specific variable that depends on the marital status and number of children associated with each alternative a woman faces. For example, the alternatives available to a married woman with one child are to remain in this state, conceive a second child, or end the union and become single. The tax rate is different for each alternative: married filing jointly with one child, married filing jointly with two children, and head of household with one child, respectively. Marital status and number of children are outcomes of the choice processes and therefore endogenous if there is serially correlated unobserved heterogeneity. Conditioning on the permanent woman-specific effect $\left(\mu_{\mathrm{i}}\right)$ and integrating it out of the likelihood function accounts for this source of endogeneity if the heterogeneity is permanent. Thus, in our analysis, the tax rate varies over time, across states, and by fertility and marital status. There was rapid growth in the tax subsidy to children for low-income women beginning in the 1980s (see Figure 1D). Much of this growth is a result of large expansions of the EITC, which provides benefits 
almost exclusively to low-income families with children (and is refundable, hence the possibility of a negative average tax rate).

The female wage rate is measured by the mean real full time average hourly earnings of women aged 16-47. The state-year-specific mean wage rate is constructed separately for whites, blacks, and Hispanics using data from the Current Population Survey (CPS) by dividing weekly earnings in the survey week by hours of work per week. The age group 16-47 spans the (employment-eligible) age range of the NLSY sample in the years for which we have data. In order to avoid introducing composition effects into the wage trends, we regression-adjust wages for education and age. The wage measures used here are standardized to a constant level of education (high school graduate) and age (26-30). The male wage rate is constructed in the same way, for a sample of men aged 18-49. Note that the wage rate is not choice-specific: it is not conditioned on marital status or fertility. It is also not conditioned on the education or other human capital characteristics of the women in our sample. Figures $1 \mathrm{E}-1 \mathrm{G}$ show that the malefemale wage gap narrowed for all three groups through the mid 1990s, especially for Hispanics, but has been relatively constant more recently. In absolute terms, only for white and Hispanic women are mean real wages higher in 2004 than in the 1970s.

\section{Results}

The parameter estimates and standard errors on the policy and labor market variables are reported in Appendix Table A-2. ${ }^{18}$ The parameter estimates are not particularly informative, so

${ }^{18}$ In addition to the contextual variables, the specification includes black and Hispanic indicators, a quadratic in the woman's age, the number of children fathered by the current man, the cumulative number of cohabitations, whether a single woman was in a cohabitation or a 
we do not discuss them. The specification reported here includes the six contextual variables described above, each interacted with indicators for black and Hispanic, thus allowing the effects to differ freely by race/ethnicity. The specification also includes dummies for nine census regions and the 22 largest states, a quadratic in calendar time, dummies for five (or in some cases ten) year periods, and dummies for several individual years in the mid 1990s, around the time of welfare reform. The model is nonlinear and has a large number of parameters. Given the relatively small numbers of women from the less-populated states, as well as the low frequency with which some alternatives were chosen in some of the calendar years, it was not feasible to incorporate full sets of state fixed effects and calendar year fixed effects, leading us to group some of them together instead. The geographic and time controls are included in order to avoid attributing the effects of unobserved differences across states and over time to the contextual variables of interest. However, the geographic controls also absorb the true effects of permanent cross-state differences in the contextual variables, as well other permanent differences across states, thus leaving only variation over time around state-specific averages to identify the effects

marriage in her previous spell, quadratics in the ages of her youngest and oldest children, and quadratics in the duration of cohabitation and single spells. See Appendix Table A-3 for the parameter estimates on these variables. In the interests of empirical tractability we imposed a substantial number of exclusion restrictions in cases in which a given variable consistently had small and statistically insignificant effects. In alternative specifications, we found that the mother's date of birth, number of marriages, total number of children, duration of marriage, and duration of pregnancy could be excluded with little impact on the predictions of the model. The estimates of the factor loadings and probability weight shown in Table A-3 are jointly highly significant, and imply a plausible correlation structure among the disturbance. For example, the disturbance in the union dissolution alternative (choice 3 ) is negatively correlated with the other disturbances, indicating that unobserved factors that increase the likelihood of ending a union are negatively correlated with unobserved factors that increase the propensity to enter a union and bear children. The correlation between the disturbances in the conceive- a- child- with- a- newman and marry- a- new- man alternatives is 0.46 . 
of the contextual variables (Keane and Wolpin, 2002). Below, we discuss the sensitivity of the results to specifications with alternative sets of geographic controls.

We use the parameter estimates to simulate the life history of each woman in the sample. The simulations condition only on the woman's race/ethnicity, age, and the state of residence in each year in which she is observed. A woman is assigned a heterogeneity type (a value of $\mu$ ) based on a draw from the estimated heterogeneity distribution. Each woman starts out single and with no children at age 12 . The estimates are used to compute the probability of each of the three events in the choice set in this case (enter a cohabitation, enter a marriage, conceive a child), given her type $(\mu)$, race/ethnicity, and state of residence at age 12. A random number generator determines which, if any, event occurs. If the event is conceiving a child, a pregnancy duration is randomly assigned by drawing from the observed distribution of pregnancy durations in the sample. The $Y_{i t}$ variables are updated according to which event, if any, occurred, and the process is repeated for the next month. If pregnant, the birth occurs at the assigned duration. The simulation continues through the last month in which the woman is observed in the data. ${ }^{19}$ This procedure is repeated 100 times for each woman. To generate standard errors for the simulations, we took 200 random draws from the joint distribution of the parameter estimates, and repeated the entire simulation procedure for each draw. We report the mean and standard deviation of the resulting simulations.

In the baseline simulation the contextual variables take on their observed values. Table A-

${ }^{19}$ The simulated data for children are truncated at age 18 . As in the data, some children are not observed for their entire childhood in the simulations, because they have not reached age 18 in the last period in which the mother is observed. In the simulations, there are no deaths, no twin births, and no cases in which children move in or out of the mother's household. 
4 in the Appendix compares simulation results for selected variables characterizing choice behavior to the observed values in the data. ${ }^{20}$ The model reproduces most aspects of the data reasonably well, but under predicts the proportion of childhood living without any man present. Table A-5 illustrates the fit of the model to transitions of children among the five family structure categories of interest. This is a demanding measure of fit, since these transition probabilities are not directly estimated, but rather are derived from the underlying transition probabilities of women among states. The upper panel compares simulated and actual transition probabilities averaged over all ages from 0 through 17 . The model fits the transition probabilities very well in some cases, such as transitions involving a man entering the household (rows 1-4), breakup of cohabitations and marriages with stepfathers (rows 7 and 10). The simulations underestimate the rate of dissolution of marriage to the biological father (row 9), and overestimate the rate at which cohabitations are converted to marriages (rows 6 and 8 ) and the rate at which cohabitations with the biological father break up (row 5). The fit averaged over ages 0-5 shown in the lower part of the table is similar to the fit average over all ages.

To illustrate the effects of wage rates and the welfare benefit, we compare two scenarios (separately for each variable): one in which the variable is held constant for all women and all periods at its overall sample mean, and another in which it is held constant at the mean plus one standard deviation. For the tax rate we compare one scenario in which the tax rate for each combination of marital status and number of children is held constant at its sample mean to three alternative counterfactuals: one in which the tax gain from marriage is eliminated; a second in

\footnotetext{
${ }^{20}$ Tables A-4 and A-5 use the actual parameter values rather than drawing from the parameter distribution, so no standard deviations are reported.
} 
which the tax gain from having children conditional on marriage is eliminated; and a third in which the tax gain from having children conditional on being unmarried is eliminated (see the notes to Table 2 for details). For welfare reform and unilateral divorce, the two scenarios hold the variable constant at zero and at one. The values of the contextual variables used in the simulations are shown in Table 2.

Table 3 shows simulated effects of the contextual variables on the proportion of childhood spent in the five family structures of interest. The results show that an increase in the average female wage rate causes an increase in the proportion of childhood spent living with no father. The effect is very small for children of white mothers, but is large for children of black and Hispanic mothers. The implied wage elasticities of the proportion of childhood spent with no father are 1.36 for children of black mothers and 3.64 for children of Hispanic mothers. ${ }^{21}$ Another way to illustrate the magnitude of these effects is to note that the mean real wage rate of black women fell by more than one standard deviation, from over $\$ 10$ to $\$ 8.50$, from the mid 1970s to the early 1990s (see Figure 1). The results in Table 3 imply that this decline would have reduced the proportion of childhood spent with no father by more than 0.06 , from a baseline of 0.33. Most of the increase in the proportion of childhood spent living with no man comes at the expense of time spent with the married biological father.

The effects of an increase in the male wage rate are almost all opposite in sign to the effects of an increase in the female wage rate. This is consistent with the prediction of Becker's

${ }^{21}$ From Table 2, a one standard deviation increase in the wage rate is a $13.4 \%$ change. The baseline simulated proportion of childhood spent living with no father is 0.33 for blacks and 0.12 for Hispanics (see Appendix Table A-3). The simulated change of 0.060 for blacks in Table 3 is an $18.2 \%$ increase over the baseline value, yielding an elasticity of $1.36=18.2 / 13.4$. For Hispanics, the corresponding elasticity estimate is $3.64=47.5 / 13.4$. 
model of specialization in marriage. The simulated effects are small for children of white and black mothers. For children of Hispanic mothers an increase in the male wage causes a decline in time spent with no father and with a married step father, accompanied by an increase in time spent living with the married biological father. The decline of .037 in the proportion of childhood spent with no father is quite large relative to the baseline of .122 for children of Hispanic mothers.

These hypothetical exogenous changes in average market wage rates affect behavior presumably because the wage offers available to individuals in our sample are drawn from the corresponding market wage distributions. The estimates can be interpreted as reduced form effects, showing how changes in average market wages affect family structure without identifying the underlying mechanisms of the effects. Thus we cannot identify how an increase in the mean wage offer affects the distribution of wage offers by skill or ability, nor the effect of wage offers on employment decisions. The advantage of the approach is that it is feasible to estimate the net impact of wages on all of the demographic behaviors that determine family structure.

An increase in the welfare benefit is estimated to cause a decrease in the proportion of childhood spent living with the married biological father for all three groups, but the estimates are not significantly different from zero. The negative effect is consistent with the predictions of economic models of the family (e.g. Neal, 2004; Willis 1999). The decrease is accompanied by an increase in time spent living with no man (except for blacks) and cohabiting men, but the proportion of childhood spent living with a married step father also increases.

The simulated effects of the tax gains to marriage are quite small and precisely estimated, 
in the sense that we can reject large effects with considerable confidence. The simulated effects of the tax gain from having children conditional on being married are also quite small in most cases, but a few of the effects are a bit larger. It is surprising that the tax gain from children conditional on marriage is estimated to cause a decrease in the proportion of childhood spent living with a married father, by about 0.025 for all three groups, accompanied by an increase in time spent living with no father. This is a puzzling finding, and is robust across the alternative specifications we have estimated. The simulated effects of the tax gain from children conditional on being unmarried are also counterintuitive, resulting in an increase time spent with the married biological father and a decline in time spent with no father present. ${ }^{22}$

The last two panels in Table 3 show the simulated effects of welfare reform and unilateral divorce. The simulations reveal some moderately large effects in a few cases, but none are significantly different from zero. Welfare reform is estimated to cause an increase of .049 in the proportion of childhood lived with the married biological father for children of black mothers. Unilateral divorce also causes a rather large increase in the proportion of childhood living with the married biological father for children of black and Hispanic mothers. The lack of precision of these estimates is probably due to the fact that most of the changes in unilateral divorce laws were in the early 1970s (see Figure 1C), so these changes affected relatively few individuals in our sample during the prime childbearing years. Welfare reform occurred in a fairly narrow time

\footnotetext{
${ }^{22}$ The simulation of the effects of the tax gain from an additional child within marriage holds constant the tax gain from an additional child outside of marriage, and vice versa. Further examination of these effects would require an analysis of income and substitution effects (both within and across periods) of the tax gain on labor supply and earnings. Note that in a household bargaining model with divorce and child support transfers, the impact of an EITC-type tax credit, which is especially beneficial to single mothers, on divorce has an ambiguous sign (Francesconi et al., 2007).
} 
span from the late 1980s through 1997 when the NLSY79 cohort was in their 30s, past prime childbearing ages.

Family structure changes are thought to have different effects on children in different stages of childhood (e.g. Hill et al., 2001; Moore et al. 2001). We examined whether the effects shown in Table 3 were concentrated in particular phases of childhood: early (0-4), middle (5-11), and late (12-17). These are hypothesized by developmental psychologists to be distinct stages in the developmental life course. The results (not shown) do not indicate any systematic tendency for the effects to be concentrated in particular stages of childhood. In a few cases, the effects are stronger at younger ages (e.g. welfare reform for blacks), while in a few other cases the effects are stronger at older ages (e.g. tax gain to having children for whites). In the great majority of cases the effects are quite similar across the age groups.

The outcomes shown in Table 3 are measures of the "stock" of time spent in alternative family structures. It is of considerable interest to investigate the underlying determinants of these stocks, which include both a child's family structure at birth, and "flows" of men in and out of a child's household. Consider the effect of a one standard deviation increase in the female wage rate, which was estimated to cause an increases of 0.060 and 0.057 in the proportion of childhood living with no father for children of black and Hispanic mothers, respectively. The simulated increase in the probability that the mother was single at the birth of the child is 0.038 (se 0.035 ) for blacks and 0.056 (se 0.031) for Hispanics, accounting for a substantial part of the increase in the proportion of childhood living with no father (not shown). Figure 2 shows the simulated effects of the wage increase on annualized transition rates of children of black mothers among the various family structures, along with $95 \%$ confidence bands. The annual transition rates out 
of marriage increase by .02 to .03 , thus contributing to the increase in time spent with no father. Cohabitations break up at a more rapid rate as well. Surprisingly, transitions into cohabitation and marriage also increase. The corresponding effects for children of Hispanic mothers (not shown) are all in the same direction, but smaller and less often significantly different from zero.

Another interesting finding in Table 3 is the negative effect of a higher male wage rate for children of Hispanic mothers on the proportion of childhood living with no father (-.037), and the increase in time spent living with the married biological father (.059). The simulated effect of an increase in the male wage rate on the probability that the mother was single at the birth of the child is -.046 (se .023) for children of Hispanic mothers, which can account for all of the -.037 change in the proportion of childhood spent with no father. Changes in transition rates contribute little in this case (not shown).

We now use the estimates to address a different question: how did the observed trends in the contextual variables affect family structure, compared to a counterfactual scenario in which the contextual variables remained constant at their state-and-race/ethnicity-specific 1970-1974 means, the values that prevailed when the NLSY79 cohort of women was entering adolescence. The first panel of Table 4 shows the simulated impact of exposure to the observed values of the contextual variables compared to the counterfactual in which they all remained at their early 1970s levels. For children of white mothers, the simulations imply that changes in the contextual variables caused an increase in the proportion of childhood spent with the married biological father of 6.1 percentage points, and decreases of 2.3 percentage points in time with a married step father, and 3.2 percentage points in time spent with no father. These are moderately large effects, given the simulated baseline proportions of $87 \%$ with a married biological father, $5 \%$ with a 
married step father, and 7\% with no father (see Appendix Table A-3). The simulated effects for the children of black mothers are similar in sign and magnitude, but are not as precisely estimated. The effects for Hispanics are substantially smaller. These results imply that if the contextual variables had remained at their early values during the past 30 years, the proportion of time children lived without their biological father (or without any father) would have been even larger than the observed proportions.

The remaining panels of Table 4 show the effects of changing one variable at a time. An important source of the total effects for whites and blacks is the change in the average tax rate, which declined substantially for families with children beginning in the mid 1980s. This was reinforced by a declining female wage rate for blacks. For whites, the decline in the welfare benefit also contributed to the observed changes. For Hispanics, female and male wage trends that both caused less time spent in marriage and with the biological father were offset by the effects of trends in tax rates and welfare benefits. Because female and male wage rates tend to move in the same direction and have opposite effects on most behaviors, the relatively large effects of both male and female wages for blacks and Hispanics shown in Table 3 tend to cancel each other out. The effects of welfare reform and unilateral divorce are negligible for all three groups, not surprising given the small estimates in Table 3.

The final issue considered here is whether the model can explain the large changes in family structure in recent decades in the U.S. There are no consistent time series available from the 1970s onward on children living in cohabiting arrangements and on biological versus step fathers, so the only trend we can analyze is the proportion of children living with the mother only. We compare results from two counterfactual simulations in order to determine how much 
of the observed trend in the proportion of children living with no father from the early 1970s through the early 2000s can be explained by our model: in one case we hold all the contextual variables constant at their 1970-1974 state-race/ethnicity-specific means, and in the other case we hold them all constant at the corresponding 2000-2004 values. Comparing the two simulations gives an estimate of the effect of the observed changes in contextual variables on the proportion of childhood spent living with no father.

Table 5 uses CPS data to show that the proportion of children living with no father increased from 0.095 to 0.191 for whites from $1970-74$ to $2000-04$, and from 0.388 to 0.572 for blacks. For Hispanics, the time series begins in 1980, and there was a small increase from 0.253 to 0.278 from $1980-84$ to $2000-04$. The table shows that our simulations cannot explain any of the observed change for whites, and only a very small proportion for blacks. The simulations over-predict the magnitude of the increase for Hispanics, but it is not clear how much weight to put on this, given that the composition of the Hispanic population is changing over time, while the NLSY79 Hispanic sample is representative only as of 1979. One other series available on a consistent basis is the fraction of those children living with no father whose mother has never been married. Table 5 shows that this increased from 0.086 to 0.417 since the early 1970 s, a change of 0.331 . The observed changes in the contextual variables predict an increase of 0.037 , only about one tenth of the observed change. Thus, as in much previous research, our estimates indicate that the economic and policy variables we considered contributed little to the observed changes in family structure.

\section{Alternative specifications}


The results discussed above are based on a specification with a rich set of controls for fixed geographic effects: 22 state dummies and nine census division dummies. As discussed above, this specification has the advantage of controlling for unobserved differences across states and census divisions that could be correlated with the contextual variables. The source of identification is variation in state-specific trends in the contextual variables around the statespecific means. In order to determine whether the results are sensitive to the source of identification, we re-estimated the model with two alternative specifications: one that drops the state fixed effects, and one that drops the nine division dummies as well. Table 6 shows the simulated effects of the contextual variables on the proportion of childhood spent living with no father, for alternative model specifications. Column 1 reproduces the results for the main specification, from the last column of Table $3 .{ }^{23}$ Columns 2 and 3 report results from the new specifications. Most of the simulated effects are very similar, suggesting that responses to permanent differences across states are similar to responses to variation around means within states. There are a few notable differences, however: the effect of the welfare benefit for blacks changes from 0.005 to 0.031 ; the effect of welfare reform for blacks changes from -0.022 to 0.001; and the effect of unilateral divorce changes from - 0.049 to 0.009 for blacks and from 0.061 to -0.026 for Hispanics.

Another important feature of the specification is the absence of controls for the characteristics of women, other than race/ethnicity. The effects that we attribute to the contextual variables could be due in part to differences in characteristics of women not included in the

${ }^{23}$ The entries in column 1 of Table 6 differ slightly from the corresponding entries in Table 3 because the results in Table 6 use the actual point estimates of the parameters rather than 200 draws from the parameter distribution as in Table 3. 
specification. To investigate this possibility we estimated three alternative specifications of the model, adding controls for the woman's own family structure at age 14 , her completed years of schooling, and her cognitive achievement, as measured by the Armed Forces Qualification Test (AFQT) score. ${ }^{24}$ Columns 4-6 in Table 6 show the results for these specifications. Controlling for the woman's family structure at age 14 has very little impact on the simulated effects (compare columns 1 and 4). Adding completed years of schooling has relatively little impact as well (compare columns 4 and 5), with a couple of exceptions. But adding the AFQT score in column 6 changes the results substantially, yielding much smaller effects of several of the contextual variables. This is somewhat surprising, but it turns out that the AFQT score is positively correlated with all of the contextual variables, with a correlation as high as 0.27 with the male wage rate. And the correlation between education and both the male wage and the average tax rate is 0.10 . This is presumably due to cross-state correlations between AFQT, education, and state-specific time variation in the contextual variables. Thus the effects that we attribute to the contextual variables may be due in part to education and cognitive ability. However, both education and cognitive ability are malleable, and the contextual variables may affect family structure in part via effects on education and cognitive ability of mothers. This is an interesting possibility to examine in future research.

\section{Conclusions}

The evidence presented here indicates that family structure experiences of the children of

\footnotetext{
${ }^{24}$ Education and AFQT are treated as exogenous, and we do not attach any specific interpretation to their effects.
} 
women born from 1957 to 1964 are affected by male and female wage rates and tax rates. Welfare benefits, welfare reform, and unilateral divorce are estimated to have relatively little impact on family structure. The results show that both the magnitudes of the effects and the channels through which they operate are often quite different for whites, blacks, and Hispanics. The methods used to produce this evidence are rather new, and the consistency between our findings and those of previous studies, for the outcomes that can be compared, is encouraging. But we readily acknowledge several limitations that suggest caution in drawing any strong conclusions based on the results.

First, our results apply to a narrow range of birth cohorts, and it is difficult to see how to generalize them in the absence of comparable data for other cohorts. Second, a limitation of the NLSY79 data is that we have little information on children who do not live with the biological mother. Thus while our model is rich, it omits this potentially important channel through which the contextual variables could affect family structure. Third, we do not model the processes that determine other potentially important aspects of family structure, such as the presence in the household of step siblings and grandparents. Temporary separations are ignored as well. And a potentially important channel through which several of the contextual variables may operate is the labor market, suggesting the need to model employment choices. All of these channels are worth exploring in future work.

An important motivation for our analysis was the challenge posed by Ellwood and Jencks (2004) to develop new approaches to analyzing the determinants of family structure change. We believe that our analysis has been successful in responding to several of their suggestions for new directions in this field. But the results of our analysis imply that trends in the contextual variables 
considered here cannot account for the trend away from traditional family structure in the last 30 years. Explaining this trend remains an important challenge. Another challenge that we are pursuing in ongoing research is to develop a theoretical model that can provide an explanation and interpretation of the main results, including the large differences across racial and ethnic groups. 


\section{Appendix A}

Here we describe how the likelihood function was modified to deal with missing data, uncertain dates of events, and uncertain sequences of events. To do this, it is convenient to rewrite the likelihood function in terms of spells of time spent in a given state. States are defined by $Y_{i t}$. For example, when a woman first becomes at risk of experiencing demographic events at age 12 , she is single, not pregnant, and there is no current man. This defines a particular state. If a woman is married and not pregnant, this defines a second state. There are a total of eight states. A woman who is in a particular state remains in that state until she experiences one of the events in her set of alternatives. See Blau and van der Klaauw (2008) for a full description of the state space.

Consider a spell in state $s$ that began in month $t$ and ended in month $n$ with the occurrence of event $j$, one of the relevant alternatives available in state $s$. Use the convention that the month in which the transition occurred is the last month in which state $s$ was occupied, and the following month is the first month in which the new state $s^{\prime}(s, j)$ is occupied. Note that the state $s^{\prime}$ occupied in the subsequent spell depends on both the event $j$ that occurred to end the spell and the state $s$ previously occupied. Modifying the notation in the text by dropping the individual subscript $(i)$ and adding a state subscript $(s)$, the probability that event $j$ occurs in month $t$ of a spell in state $s$ is

$$
P_{j s t}=\exp \left\{V_{j s t}\right\} / \sum_{k \in A\left(Y_{t}\right)} \exp \left\{V_{k s t}\right\}
$$

where

$$
V_{j s t}=\beta_{1 \mathrm{j}} X+\beta_{2 \mathrm{j}} Y_{t}+\beta_{3 \mathrm{j}} Z_{j t}+\beta_{4 \mathrm{j}} X Z_{j t}+\beta_{5 \mathrm{j}} \mu, \quad j \in A\left(Y_{t}\right)
$$

and the probability that no event occurs in month $t$ is 


$$
P_{O s t}=\exp \left\{V_{O s t}\right\} / \sum_{k \in A\left(Y_{t}\right)} \exp \left\{V_{k s t}\right\}
$$

If the spell began in period $t^{*}$ and ended in period $n$, the likelihood function contribution for the spell is (conditional on $\mu$ ):

$$
L_{j s}(t, n, \mu)=\left(\prod_{\ell=t^{*}}^{n-1} P_{0 s}\right) P_{j s n}
$$

If the spell is censored at month $n$, the last term is dropped and the upper limit of the product is $n$.

Consider a woman who experiences a total of $M$ spells. The $m^{\text {th }}$ spell begins in calendar month $t(m)$ and ends in calendar month $n(m)$. The state occupied in spell $m$ is $s(m)$, and the event causing the $m^{\text {th }}$ spell to end is $j(m)$. For simplicity, assume that none of the spells is censored except the last. The likelihood contribution for the $M$ spells observed for a given woman, conditional on $\mu$, is

$$
L(\mu)=\left[\prod_{m=1}^{M-1} L_{j(m) s(m)}(t(m), n(m), \mu)\right] L_{s(A)}(t(A), n(A), \mu),
$$

We now describe how the likelihood function is modified to deal with uncertain dates and sequences of events.

(1) The month in which an event occurred is unknown. Suppose the month in which event $j$ occurred during spell $m$ in state $s$ is not observed. We know only that the event occurred between month $r$ and month $q$. In the standard case in which the month $(n)$ in which the event occurred is known, the likelihood contribution for the pair of spells $m$ and $m+1$ is part of the product in equation (A1). Assuming for simplicity that spell $m+1$ is the last one and is censored at date $n(m+1)$, this part of the likelihood contribution is given by

$$
L(m, m+1, \mu)=L_{j(m) s(m)}(t(m), n(m), \mu) L_{s^{\prime}(m+1)}(n(m)+1, n(m+1), \mu)
$$


where $s$ is the state occupied in spell $m+1$. If we know only that the event occurred between month $r$ and month $q$, then the likelihood contribution for the pair of spells is

$$
L(m, m+1, \mu)=\sum_{a=r}^{q} L_{j(m) s(m)}(t(m), a, \mu) L_{s^{\prime}(m+1)}(a+1, n(m+1), \mu)
$$

(2) The sequence in which events occurred is uncertain. To illustrate this case, suppose the exact month in which a cohabitation began is unknown, but it is known to have begun between months $r$ and $q$. And suppose a child was conceived in month $o$, where $r<o<q$. Then we do not know whether the child was conceived before the cohabitation began or after. In this case there are two events and three spells to consider: spell $m$ (single, not pregnant), spell $m+1$ (either cohabiting and not pregnant or single and pregnant) and spell $m+2$ (cohabiting and pregnant). Let $j$ denote the event of entering a cohabitation and let $k$ represent the event of conception. Let $s$ denote the state occupied in spell $m$, and $s^{\prime}(j(m), s)$ the state occupied in spell $m+1$ if the event that terminates spell $m$ is $j(m)$, and $s^{\prime \prime}\left(j(m+1), s^{\prime}\right)$ the state occupied in spell $m+2$ if the event that terminates spell $m+1$ is $j(\mathrm{~m}+1)$. Suppose for illustration that spell $m+2$ is the last spell, and as before let $n(m+2)$ denote the censoring date for spell $m+2$. Then the likelihood contribution for the three spells is

$$
\begin{aligned}
& L(m, m+1, m+2, \mu)=\underset{a=r}{\left[\sum_{j=r} L_{j s}(t, a, \mu) L_{k s^{\prime}(\mathrm{s}, \mathrm{j})}(a+1, o)\right] L_{s^{\prime \prime}\left(s^{\prime}, k\right)}(o+1, n(m+1), \mu)} \\
& +L_{k s}(t, o, \mu)\left[\sum_{a=o+1}^{q} L_{j s^{\prime}(s, k)}(o, a, \mu) L_{s^{\prime \prime}\left(\mathrm{s}^{\prime}, \mathrm{j}\right)}(a+1, n(m+1), \mu)\right]
\end{aligned}
$$

The first line accounts for the probability that the cohabitation began before the conception occurred $(a<o)$. The second line accounts for the probability that the cohabitation began after the conception occurred $(a>o)$. Note that only one event can occur in a given month. 
(3) A single woman who has fathered at least one child outside of a union since the end of her previous union (or since age 12 if she has never been in a union) conceives a child, but we cannot determine from the data whether it is with the current man (father of the most recent child) or a new man. In this case, we know that in a given month either event 1 or event 2 occurred, but we do not know which. Suppose the conception occurred in month $q$ of spell $z$. The likelihood contribution for the woman in this case is

$$
\begin{aligned}
& L(\mu)=\left[\prod_{m=1}^{z-1} L_{j(m) s(m)}(t(m), n(m), \mu)\right. \\
& *\left\{L _ { 1 s ( z ) } ( q , n ( z ) , \mu ) \left[\prod_{m=z+1}^{A-1} L_{j(m) s(m)}(t(m), n(m), \mu \mid j=1) L_{s(A)}\left(t_{A}, n(A), \mu \mid j=1\right)\right.\right. \\
& +L_{2 s(z)}(q, n(z), \mu)\left[\prod_{m=z+1}^{A-1} L_{j(m) s(m)}(t(m), n(m), \mu \mid j=2) L_{s(A)}\left(t_{A}, n(A), \mu \mid j=2\right)\right\},
\end{aligned}
$$

where $n(z-1)=q-1$ and the conditioning on $j=1$ and $j=2$ indicates that the entire subsequent demographic history may depend on which event occurred. 


\section{Appendix B}

Wage rates. The mean hourly wage rate was computed for men and women aged 16-47 by year, state, and race/ethnicity from the Merged Outgoing Rotation Group (MORG) files of the Current Population Survey (CPS) for 1979-2004, and from the May CPS files for 1970-1978. The wage rate is computed by dividing weekly earnings by hours of work per week. Cases were included in the computation only if weekly earnings were at least $\$ 150$ (in year 2000 dollars), hours of work were at least 30, and the resulting hourly wage rate was between $\$ 2.00$ and \$200.00. Weekly wages were topcoded at \$999 from 1970-1988, \$1,923 from 1989-1997, and \$2,884 from 1998 on. Wages were deflated using the Personal Consumption Expenditure Deflator (PCED, base year 2000), and weighted by the sampling weight provided in the CPS files. Before 1977, some states are not separately identified, so for those years the mean wage for the group of states (by sex, year, and race/ethnicity) is assigned to each state in the group.

Weekly earnings are given in categorical form before 1973 in the May CPS files. The midpoint of each category is used in this case, with $\$ 600$ assigned for the highest category in 1972 (when the lower limit is \$500), and \$300 assigned in 1970-1971 (when the lower limit of the highest category is \$200). In the 1973-1978 May CPS files, the continuous weekly earnings variable is missing for some cases, but the categorical version of earnings is also on the file for those years. If the categorical variable is not missing, it is used to compute the wage when the continuous measure is missing (the categories are the same in 1973-1978 as in 1972). Hispanic ethnicity is not identified in the May CPS in 1970-1972. The real 1973 means by state were used for 1970-72 for Hispanics.

The wage rate is regressed on education dummies (four groups), age dummies (six 
groups), and state of residence, separately by year, sex, and race/ethnicity. A wage rate is predicted for each employed individual, holding education constant at high school graduate and age constant at 26-30. Wages are then averaged within state-year-sex-race/ethnicity cells. In order to smooth out spurious fluctuations due to small sample size in some cells, we use a three year moving average of wage rates, within state-sex-race/ethnicity groups. Cells with fewer than 30 cases (after averaging) are omitted. This resulted in the loss of 5.4\% of the potential NLSY person-month observations, with the loss disproportionately larger for blacks and Hispanics.

Welfare Benefit. Data for the AFDC/TANF cash benefit for a family of four with no income are from Robert Moffitt's welfare benefits file for the years 1970-1998 (http://www.econ.jhu.edu/People/Moffitt/datasets.html). Data for 1999-2004 are from the 2004 Green Book (http://www.gpoaccess.gov/wmprints/green/index.html), the Congressional Research Service (2005), and the Urban Institute's Assessing the New Federalism web site (http://www.urban.org/center/anf/index.cfm). In some recent years data are only available for a family of three. The benefit for a family of four was estimated by applying the state-specific ratio of benefits for households of size three and four, which are both available for 1996-1998 and 2003-2004. The Food Stamp guarantee for a family of four is from Moffitt's data base for 19701998, updated with data from the web site of the Food and Nutrition Service.

Welfare Reform. The timing of implementation of welfare waivers and TANF are from the web site of the Office of the Assistant Secretary for Planning and Evaluation, Department of Health and Human Services.

Divorce Law. The year of enactment of unilateral divorce is from Gruber (2004), Table 1. Tax Rates. Tax rates are computed using the NBER's TAXSIM program. Tax rates were 
computed for two income levels: the poverty line for a family of three (one adult and two related children) in $2000(\$ 13,874)$, and for median family income in $2000(\$ 50,372)$, both adjusted for inflation in other years. All income was assumed to be from earnings. Child care expenditure for a poor family was assumed to be $23 \%$ of income, and for a median-income family $6 \%$ of income (Johnson, 2005). All children were assumed to be under 17 for purposes of the child tax credit. Taxes were computed for alternative numbers of children (0-9) and filing statuses (single, head of household, and married filing jointly). State taxes are included from 1977-2004, but are not included for 1970-1976. In married families, $60 \%$ of earnings were allocated to the husband and $40 \%$ to the wife.

Assigning state of residence before the first survey and between survey years. Respondents were asked to report their state of residence at age 14 and at birth, but the dates of moves are not recorded. We assign state of residence for years before the first survey year (1979) based on which reporting year (year of birth, year in which the respondent turned age 14, and 1979) is closest in time to a given calendar year. The state of residence is reported in each interview from 1979-1994. The state reported is assumed to apply for the entire calendar year. In 1996 and 1998, state of residence is ascertained at the survey date, but the dates of moves are not recorded. We assign the 1995 and 1997 state of residence according to which interview month in the adjacent survey year is closest in time to 1995 or 1997. In 2000, 2002, and 2004, the dates of moves between interviews were recorded, so we assign state of residence for the between-survey years according to where the respondent lived longest during the between-survey years. The survey-date state of residence is assigned to the entire calendar year for that survey year. 


\section{References}

Acs, Gregory, and Sandy Nelson. 2004. "Changes in living arrangements in the 1990s: Do welfare policies matter?” Journal of Policy Analysis and Management 23 (2): 273-290.

Alesina, Alberto, and Paola Giuliano. 2006. "Divorce, Fertility, and the Shot Gun Marriage," NBER Working Paper 12375, July.

Akerlof, George, Janet Yellin, and Michael Katz. 1996. "An analysis of out-of-wedlock childbearing in the United States," Quarterly Journal of Economics 111 (2): 277-318.

Alm, James, and Leslie Whittington. 2003. Shacking Up or Shelling Out: Income Taxes, Marriage, and Cohabitation," Review of Economics of the Household 1: 169-186.

Aughinbaugh, Alison, Charles Pierret, and Donna Rothstein. 2005. "The Impact of Family Structure Transitions on Youth Achievement: Evidence from the Children of the NLSY79." Demography 42 (3): 447-468.

Becker, Gary S. 1981. A Treatise on the Family, Cambridge: Harvard University Press.

Bitler, Marianne, Jonah Gelbach, Hillary W. Hoynes, and Madeline Zavodny. 2004. "The impact of welfare reform on marriage, and divorce," Demography 41 (2): 213-236.

Bitler, Marianne, Jonah Gelbach, and Hillary W. Hoynes. 2006. "Welfare reform and children's living arrangements," Journal of Human Resources 41 (1): 1-27.

Blau, David, and Wilbert van der Klaauw, 2008. "A demographic analysis of the family structure experiences of children in the United States," Review of Economics of the Household 6: 193-221.

Blau, Francine, Lawrence Kahn, and Jane Waldfogel. 2000. “Understanding young women's marriage decisions: the role of labor and marriage market conditions," Industrial and Labor Relations Review 53 (4): 624-647.

Blau, Francine, Lawrence Kahn, and Jane Waldfogel. 2004. "The Impact of Welfare Benefits on Single Motherhood and Headship of Young Women: Evidence from the Census," Journal of Human Resources 39 (2), Spring: 382-404.

Bumpass, Larry, and Hsien-Hen Lu. 2000. "Trends in Cohabitation and Implications for Children's Family Contexts in the United States." Population Studies 54: 29-41.

Bumpass, Larry James Sweet, and Andrew Cherlin. 1991. "The Role of Cohabitation in Declining Rates of Marriage." Journal of Marriage and the Family 53 (Nov.): 913-27. 
Chase-Lansdale, P. Lindsay, Andrew Cherlin, and Kathleen Kiernan. 1995. "The Long-Term Effects of Parental Divorce on the Mental health of Young Adults: A Developmental Perspective." Child Development 66: 1614-34.

Cherlin, Andrew. 1999. “Going to Extremes: Family Structure, Children's Well-Being, and Social Science.” Demography 36 (4): 421-8.

Congressional Research Service. 2005. "TANF cash benefits as of January 1, 2004," CRS Report RL32598, September 12, Library of Congress.

DeLeire, Thomas, and Ariel Kalil. 2002. "Good things come in threes: single-parent multigenerational family structure and adolescent adjustment," Demography 39 (2): 393-413.

Dickert-Conlin, Stacy, and Scott Houser. 1998. "Taxes and transfers: A new look at the marriage penalty," National Tax Journal 51 (2): 175-217.

Ellwood, David T. 2000. The impact of the earned income tax credit and social policy reforms on work, marriage, and living arrangements," National Tax Journal 53 (4, Part 2): 1063-1105.

Ellwood, David T. and Christopher Jencks. 2004. "The Spread of Single-Parent Families in the United States Since 1960," in Daniel P. Moynihan, Timothy M. Smeeding, and Lee Rainwater (eds.) The Future of the Family, New York: Russell Sage Foundation, 25-65.

Fields, Jason And Lynne Casper. 2001. “America’s Families and Living Arrangements.” U.S. Census Bureau, Current Population Reports P20-537, June.

Fitzgerald, John, and David Ribar. 2004. "Welfare reform and female headship," Demography 41 (2): 189-212.

Foster, E. Michael, and Saul D. Hoffman. 2001. "The Young and the Not Quite So Young: Age Variation in the Impact of AFDC Benefits on Nonmarital Childbearing," in Lawrence L. Wu and Barbara Wolfe (eds.) Out of Wedlock: Causes and Consequences of Nonmarital Fertility, New York: Russell Sage Foundation, 173-201.

Francesconi, Marco. 2002. "A joint dynamic model of fertility and work of married women," Journal of Labor Economics 20 (1), Part 1: 336-380.

Francesconi, Marco, Helmut Rainer and Wilbert van der Klaauw. 2007. "The Effects of In-Work Benefit Reform in Britain on Couples: Theory and Evidence," IZA Discussion Paper 2980, August.

Friedberg, Leora. 1998. "Did unilateral divorce raise divorce rates? Evidence from panel data," American Economic Review 88 (3): 608-627. 
Gennetian, Lisa A. 2005. "One or Two Parents? Half or Step Siblings? The Effect of Family Structure on Young Children's Achievement.” Journal of Population Economics 18: 415-436.

Gennetian, Lisa A., and Cynthia Miller. 2004. "How welfare reform can affect marriage: evidence from an experimental study in Minnesota," Review of Economics of the Household 2: 275-301.

Ginther, Donna K., and Robert A. Pollak. 2004. "Family Structure and Children's Educational Outcomes." Demography 41 (4): 671-96.

Graefe, Deborah, and Daniel Lichter. 1999. "Life Course Transitions of American Children," Demography 36 (2): 205-18.

Gruber, Jonathan. 2004. "Is making divorce easier bad for children? The long-run implications of unilateral divorce for children," Journal of Labor Economics 22 (4): 799-834.

Harknett, Kristen, and Lisa Gennetian. 2003. "The effect of an earnings supplement on union formation," Demography 40 (3): 451-478.

Heckman, James J. 1981. "Heterogeneity and State Dependence" in Sherwin Rosen (ed.) Studies in Labor Markets. Chicago: University of Chicago Press.

Hetherington, M. and M. Stanley-Hagan. 1999. "The Adjustment of Children with Divorced Parents: A Risk and Resiliency Perspective." Journal of Child Psychology and Psychiatry 40 (1): 129-140.

Hill, M. S., Yeung, W. J., \& Duncan, Greg J. 2001. "Childhood family structure and young adult behaviors," Journal of Population Economics 14: 271-299.

Hofferth, Sandra L. (2006). "Residential Father Family Type and Child Well-being: Investment Versus Selection.” Demography 43 (1): 53-78.

Hoffman, Saul D., and E. Michael Foster. 2000. "AFDC benefits and nonmarital births to young women," Journal of Human Resources 35 (2): 376-391.

Hotz, V. Joseph, and Karl Scholz. 2003. “The Earned Income Tax Credit,” in Robert A. Moffitt (ed.) Means Tested Transfer Programs, Chicago: University of Chicago for the National Bureau of Economic Research.

Johnson, Julia O. 2005. "Who's Minding the Kids? Child Care Arrangements: Winter 2002," U.S. Census Bureau Current Population Reports P70-101, October. 
Kaestner, Robert, Sanders Korenman, and June O'Neill. 2003. "Has Welfare Reform Changed Teenage Behaviors?” Journal of Policy Analysis and Management 22 (2): 225-248.

Keane, Michael, and Kenneth Wolpin. 2002. "Estimating Welfare Effects Consistent With Forward-Looking Behavior. Part I: Lessons from a Simulation Exercise," Journal of Human Resources 37 (3): 570-99.

Keane, Michael P., and Kenneth I. Wolpin. 2006. "The Role of Labor and Marriage Markets, Preference heterogeneity and the Welfare System in the Life Cycle Decisions of Black, Hispanic, and White Women," PIER Working Paper 06-004, University of Pennsylvania.

Kreider, Rose M. 2008. "Living Arrangements of Children: 2004," Current Population Reports, P70-114. U.S. Census Bureau, Washington D.C.

Lang, Kevin, and Jay Zagorsky. 2001. "Does Growing Up With A Parent Absent Really Hurt?” Journal of Human Resources 36 (2): 253-73.

Light, Audrey, and Yoshiaki Omori. 2006. "Economic Incentives and Family Formation," Working Paper, Department of Economics, Ohio State University, Working Paper, February.

MaCurdy, Thomas, Thomas Mroz, and R. Mark Gritz (1998). "An evaluation of the NLSY," Journal of Human Resources 33 (2): 345-436.

Martin, J., B. Hamilton, S. Ventura, F. Menaker, and M. Park. 2002. "Births: Final Data for 2000.” National Center for Health Statistics, National Vital Statistics Reports, 50 (6), Feb. 12.

McLanahan, Sara, and Gary Sandefur. 1994. Growing Up With A Single Parent. Cambridge: Harvard University Press.

Moffitt, Robert A. 1998. "The effect of welfare on marriage and fertility," in Robert A. Moffitt (ed.) Welfare, The Family, and Reproductive Behavior: Research Perspectives Washington D.C.: National Academy Press: 50-97.

Moffitt, Robert A. 2001. "Welfare Benefits and Female Headship in U.S. Time Series," in Lawrence L. Wu and Barbara Wolfe (eds.) Out of Wedlock: Causes and Consequences of Nonmarital Fertility, New York: Russell Sage Foundation, 143-172.

Moore, K. A., Evans, V. J., Brooks-Gunn, J., \& Roth, J. 2001. "What are good child outcomes?" In A. Thornton (Ed.), The well-being of children and families: Research and data needs (pp. 59-84). Ann Arbor: University of Michigan Press.

Neal, Derek. 2004. "The Relationship Between Marriage Market Prospects and Never-Married Motherhood," Journal of Human Resources 39 (4): 938-57.

Peters, H. Elizabeth. 1986. "Marriage and divorce: Informational Constraints and private 
contracting," American Economic Review 76 (3): 437-454.

Rosenzweig, Mark. 1999. "Welfare, Marital Prospects, and Nonmarital Childbearing," Journal of Political Economy 107 (6, part 2): S3-32.

Seitz, Shannon. 2009. "Accounting for Racial Differences in Marriage and Employment," Journal of Labor Economics 27 (3): 385-438.

Sigle-Rushton, W., J. Hobcroft, and K. Kiernan. 2005. "Parental Divorce and Subsequent Disadvantage: A Cross-Cohort Comparison." Demography 42 (3): 427-446.

Stevenson and Justin Wolfers. 2007. "Marriage and Divorce: Changes and Their Driving Forces," Journal of Economic Perspectives 21 (2):27-52.

Swann, Christopher A. 2005. "Welfare reform when recipients are forward looking," Journal of Human Resources 40 (1): 31-56.

Thomson, Elizabeth, Thomas L. Hanson, and Sara McLanahan. 1994. "Family structure and child well-being: economic resources vs. parental behaviors," Social Forces 73 (1): 221-42

Tartari, Melissa. 2006. "Divorce and the Cognitive Achievement of Children," Working Paper, Yale University.

Van der Klaauw, Wilbert. 1996. "Female Labour Supply and Marital Status Decisions: A LifeCycle Model”, Review of Economic Studies 63(2): 199-235.

Willis, Robert. 1999. "A Theory of Out of Wedlock Childbearing," Journal of Political Economy 107 (6, Part 2): S33-64.

Wolfers, Justin. 2006. "Did unilateral divorce laws raise divorce rates? A Reconciliation and New Results," American Economic Review 96 (5): 1802-20. 
Table 1: Descriptive Statistics on Women and Children as of the Last Interview

\begin{tabular}{|l|l|l|l|}
\hline & White & Black & Hispanic \\
\hline Demographic outcomes of women & & & \\
\hline Number of children born & 1.71 & 1.89 & 1.99 \\
\hline No children born & 0.21 & 0.18 & 0.17 \\
\hline Ever married & 0.89 & 0.62 & 0.82 \\
\hline Ever cohabited & 0.43 & 0.36 & 0.39 \\
\hline Age at last observation & 40.5 & 39.9 & 39.6 \\
\hline Number of women & 2,292 & 1,338 & 846 \\
\hline Family structure outcomes of children & & & \\
\hline Ever lived with no father & 0.31 & 0.76 & 0.45 \\
\hline Ever lived with married father & 0.95 & 0.61 & 0.87 \\
\hline Biological & 0.92 & 0.47 & 0.79 \\
\hline Step & 0.14 & 0.20 & 0.17 \\
\hline Ever lived with cohabiting father & 0.14 & 0.27 & 0.23 \\
\hline Biological & 0.04 & 0.10 & 0.09 \\
\hline Step & 0.11 & 0.18 & 0.16 \\
\hline Ever lived with biological father & 0.94 & 0.52 & 0.85 \\
\hline Ever lived with stepfather & 0.18 & 0.28 & 0.24 \\
\hline Age of child at last observation & 12.9 & 14.0 & 13.3 \\
\hline Number of children & 3,864 & 2,496 & 1,667 \\
\hline
\end{tabular}

Notes: The last interview was in 2004 for $72 \%$ of women. The child outcomes are censored at age 18. Observations are weighted by the inverse of the number of event histories per woman. As described in the text, a woman may have multiple event histories if there is ambiguity about the timing or sequence in which demographic events occurred. In these cases, an event history is generated for each of the feasible timing or sequencing alternatives. See the text and Appendix A for further discussion. 
Table 2: Summary Statistics on Contextual Variables

\begin{tabular}{|c|c|c|}
\hline \multicolumn{3}{|c|}{ A. Means and standard deviations } \\
\hline & Mean & $\mathrm{SD}$ \\
\hline Monthly welfare benefit for a family of four with no income & 1,013 & 265 \\
\hline Unilateral divorce law in effect & .552 & \\
\hline Welfare reform in effect & .210 & \\
\hline Male hourly wage rate & 12.12 & 1.80 \\
\hline Female hourly wage rate & 9.70 & 1.30 \\
\hline
\end{tabular}

\begin{tabular}{|l|l|l|l|l|l|l|l|l|l|l|}
\hline \multicolumn{10}{|c|}{ B. Mean tax rate by marital status and number of children } \\
\hline $\begin{array}{l}\text { Number of } \\
\text { children: }\end{array}$ & 0 & 1 & 2 & 3 & 4 & 5 & 6 & 7 & 8 & 9 \\
\hline Married & .170 & .061 & .030 & .028 & .027 & .027 & .026 & .026 & .025 & .025 \\
\hline Single & .228 & .077 & .035 & .031 & .030 & .028 & .028 & .027 & .027 & .026 \\
\hline
\end{tabular}

Note: Unit of observation is a state-year-race/ethnicity cell. Observations are weighted by the cell sample size in the NLSY sample. Dollar amounts are in year 2000 dollars, using the Personal Consumption Expenditure Deflator. The simulations reported in Table 3 use the means reported here as the baseline. The welfare benefit and wage counterfactual simulations add one standard deviation to the mean. The counterfactual for the "eliminate the gain to marriage" simulation replaces the tax rates for singles with the tax rates for married couples. The counterfactual for the "eliminate the gain to having children if married" simulation replaces the tax rates for married couples with children with the tax rate for married couples without children (.170). The counterfactual for the "eliminate the gain to having children if single" simulation replaces the tax rates for single women with children with the tax rate for single women without children (.228). The unilateral divorce and welfare reform simulations compare values of zero to one. 
Table 3: Simulated Effects of Changes in Contextual Variables on the Proportion of Childhood Spent in Alternative Family Structures

\begin{tabular}{|c|c|c|c|c|c|}
\hline & \multicolumn{5}{|c|}{ Change in proportion of childhood lived with the biological mother and: } \\
\hline & $\begin{array}{l}\text { Married biological } \\
\text { father }\end{array}$ & $\begin{array}{l}\text { Cohabiting } \\
\text { biological father }\end{array}$ & $\begin{array}{l}\text { Married step } \\
\text { father }\end{array}$ & $\begin{array}{l}\text { Cohabiting } \\
\text { Step father }\end{array}$ & No father \\
\hline \multicolumn{6}{|c|}{ Female wage rate } \\
\hline White & $.001(.016)$ & $-.001(.002)$ & $-.002(.006)$ & $-.001(.001)$ & $.002(.009)$ \\
\hline Black & $-.049(.032)$ & $-.005(.003)$ & $-.003(.008)$ & $-.003(.003)$ & $.060(.030)$ \\
\hline Hispanic & $-.077(.043)$ & $-.002(.003)$ & $.020(.010)$ & $.001(.004)$ & $.057(.033)$ \\
\hline \multicolumn{6}{|c|}{ Male wage rate } \\
\hline White & $-.019(.018)$ & $.001(.002)$ & $.008(.007)$ & $.002(.002)$ & $.008(.010)$ \\
\hline Black & $-.011(.035)$ & $.017(.012)$ & $-.003(.012)$ & $.011(.008)$ & $-.014(.028)$ \\
\hline Hispanic & $.059(.025)$ & $-.002(.003)$ & $-.016(.009)$ & $-.003(.003)$ & $-.037(.014)$ \\
\hline \multicolumn{6}{|c|}{ Welfare Benefit } \\
\hline White & $-.021(.015)$ & $.000(.001)$ & $.010(.006)$ & $.002(.002)$ & $.009(.009)$ \\
\hline Black & $-.004(.038)$ & $.002(.004)$ & $.007(.012)$ & $.002(.004)$ & $-.008(.032)$ \\
\hline Hispanic & $-.037(.025)$ & $.002(.003)$ & $.016(.008)$ & $.005(.004)$ & $.014(.016)$ \\
\hline \multicolumn{6}{|c|}{ Tax gain from marriage } \\
\hline White & $-.001(.002)$ & $.000(.001)$ & $.001(.001)$ & $.000(.001)$ & $.000(.001)$ \\
\hline Black & $-.009(.006)$ & $.000(.001)$ & $.003(.002)$ & $.000(.001)$ & $.006(.004)$ \\
\hline Hispanic & $-.007(.006)$ & $.001(.001)$ & $.002(.002)$ & $.000(.001)$ & $.004(.003)$ \\
\hline \multicolumn{6}{|c|}{ Tax gain from a child if married } \\
\hline White & $-.025(.008)$ & $-.000(.001)$ & $.007(.003)$ & $.001(.001)$ & $.017(.005)$ \\
\hline Black & $-.025(.026)$ & $.002(.002)$ & $-.003(.011)$ & $.003(.003)$ & $.022(.024)$ \\
\hline Hispanic & $-.026(.021)$ & $.001(.003)$ & $.001(.007)$ & $.002(.003)$ & $.021(.013)$ \\
\hline \multicolumn{6}{|c|}{ Tax gain from a child if single } \\
\hline White & $.058(.020)$ & $.000(.001)$ & $-.017(.007)$ & $-.002(.002)$ & $-.038(.013)$ \\
\hline Black & $.011(.036)$ & $-.005(.005)$ & $.013(.015)$ & $-.005(.006)$ & $-.014(.032)$ \\
\hline Hispanic & $.041(.039)$ & $-.003(.005)$ & $-.001(.010)$ & $-.005(.006)$ & $-.032(.026)$ \\
\hline \multicolumn{6}{|c|}{ Welfare reform } \\
\hline White & $-.003(.020)$ & $-.001(.002)$ & $.004(.010)$ & $-.001(.002)$ & $.001(.011)$ \\
\hline Black & $.049(.060)$ & $-.001(.005)$ & $-.021(.019)$ & $-.004(.004)$ & $-.023(.046)$ \\
\hline Hispanic & $.008(.037)$ & $-.002(.004)$ & $.010(.014)$ & $-.001(.004)$ & $-.013(.021)$ \\
\hline \multicolumn{6}{|c|}{ Unilateral divorce } \\
\hline White & $-.004(.030)$ & $-.001(.004)$ & $.002(.011)$ & $.000(.003)$ & $.004(.017)$ \\
\hline Black & $.066(.068)$ & $-.002(.007)$ & $-.010(.021)$ & $-.005(.007)$ & $-.049(.054)$ \\
\hline Hispanic & $.102(.065)$ & $-.007(.009)$ & $-.022(.018)$ & $-.009(.009)$ & $-.064(.044)$ \\
\hline
\end{tabular}

Notes: The five family structures are mutually exclusive and exhaustive, so the entries in each row sum to zero. Standard errors are in parentheses, computed as described in the text. Entries in bold are significantly different from zero at the $10 \%$ level. The wage rate and welfare benefit simulations show the effect of a one standard deviation increase, relative to the mean. The tax gain simulations show the effect of the observed mean tax rates relative to the counterfactual of the tax rate for singles set equal to the tax rate for married households (tax gain to marriage), the tax rate for married families with children set equal to the tax rate for married families with no children (tax gain from a child if married), and the tax rate for single mothers with children set equal to the tax rate for single mothers with no children (tax gain from a child if single). The welfare reform and unilateral divorce simulations show the effect of setting the variable equal to one, relative to setting it equal to zero. See Table 2 for the data values used in the simulations. Childhood is defined as birth up to but not including age 18. 
Table 4: Simulated Effects of Observed Changes in Contextual Variables

\begin{tabular}{|c|c|c|c|c|c|}
\hline & \multicolumn{5}{|c|}{ Proportion of Childhood lived with the biological mother and: } \\
\hline & $\begin{array}{l}\text { Married } \\
\text { biological } \\
\text { father }\end{array}$ & $\begin{array}{l}\text { Cohabiting } \\
\text { biological } \\
\text { father }\end{array}$ & $\begin{array}{l}\text { Married step } \\
\text { father }\end{array}$ & $\begin{array}{l}\text { Cohabiting } \\
\text { Step father }\end{array}$ & No father \\
\hline \multicolumn{6}{|l|}{ All } \\
\hline White & $.061(.026)$ & $-.002(.002)$ & $-.023(.010)$ & $-.006(.004)$ & $-.032(.016)$ \\
\hline Black & $.050(.040)$ & $-.009(.006)$ & $.000(.010)$ & $-.010(.006)$ & $-.038(.034)$ \\
\hline Hispanic & $.001(.037)$ & $-.010(.009)$ & $-.001(.011)$ & $-.005(.006)$ & $.014(.022)$ \\
\hline \multicolumn{6}{|c|}{ Female wage rate } \\
\hline White & $-.001(.004)$ & $.000(.001)$ & $.001(.001)$ & $.000(.001)$ & $.001(.003)$ \\
\hline Black & $.023(.009)$ & $.002(.001)$ & $.004(.005)$ & $.002(.001)$ & $-.029(.011)$ \\
\hline Hispanic & $-.021(.011)$ & $-.001(.002)$ & $.008(.004)$ & $.000(.001)$ & $.014(.006)$ \\
\hline \multicolumn{6}{|c|}{ Male wage rate } \\
\hline White & $.019(.018)$ & $-.001(.002)$ & $-.008(.006)$ & $-.002(.002)$ & $-.006(.010)$ \\
\hline Black & $-.017(.017)$ & $-.009(.005)$ & $.008(.007)$ & $-.006(.004)$ & $.022(.018)$ \\
\hline Hispanic & $-.035(.015)$ & $.001(.002)$ & $.003(.005)$ & $.002(.002)$ & $.030(.012)$ \\
\hline \multicolumn{6}{|c|}{ Welfare Benefit } \\
\hline White & $.017(.012)$ & $-.000(.001)$ & $-.008(.004)$ & $-.002(.001)$ & $-.007(.007)$ \\
\hline Black & $.005(.025)$ & $-.002(.004)$ & $-.007(.007)$ & $-.002(.003)$ & $.004(.022)$ \\
\hline Hispanic & $.020(.013)$ & $-.002(.002)$ & $-.007(.004)$ & $-.003(.002)$ & $-.009(.009)$ \\
\hline \multicolumn{6}{|l|}{ Tax Rate } \\
\hline White & $.021(.009)$ & $-.000(.001)$ & $-.007(.003)$ & $-.001(.001)$ & $-.013(.005)$ \\
\hline Black & $.031(.028)$ & $-.002(.003)$ & $-.004(.006)$ & $-.003(.002)$ & $-.023(.022)$ \\
\hline Hispanic & $.041(.027)$ & $-.005(.005)$ & $-.009(.006)$ & $-.003(.003)$ & $-.024(.016)$ \\
\hline \multicolumn{6}{|c|}{ Welfare reform } \\
\hline White & $.001(.003)$ & $-.001(.001)$ & $-.001(.002)$ & $.000(.001)$ & $.000(.002)$ \\
\hline Black & $-.002(.005)$ & $-.001(.001)$ & $.000(.003)$ & $-.001(.001)$ & $.003(.005)$ \\
\hline Hispanic & $.001(.004)$ & $-.001(.001)$ & $.002(.002)$ & $-.000(.001)$ & $-.002(.004)$ \\
\hline \multicolumn{6}{|c|}{ Unilateral divorce } \\
\hline White & $-.000(.005)$ & $-.000(.001)$ & $.000(.002)$ & $-.000(.001)$ & $.001(.003)$ \\
\hline Black & $.007(.007)$ & $-.000(.001)$ & $-.001(.002)$ & $-.001(.001)$ & $-.004(.007)$ \\
\hline Hispanic & $.008(.006)$ & $-.001(.001)$ & $-.002(.002)$ & $-.001(.001)$ & $-.005(.004)$ \\
\hline
\end{tabular}

Notes: The five family structures are mutually exclusive and exhaustive, so the entries in each row sum to zero. Standard errors are in parentheses, computed as described in the text. Entries in bold are significantly different from zero at the $10 \%$ level. The simulations compare the baseline, in which all contextual variables take on their observed values, to a counterfactual in which a given contextual variable is held constant at its state-specific 1970-1974 mean value. For the tax rate, the 1977-1981 means are used, because state taxes were not included in the 1970-1974 data. In all cases, the state fixed effects, division fixed effects, time trends, and period effects take on their actual values. 
Table 5: Comparison of Actual and Simulated Trends in Living Arrangements of Children

\begin{tabular}{|c|l|l|l|l|}
\hline & \multicolumn{3}{|c|}{ Actual Trend } & Simulation \\
\hline & $2000-04$ & $1970-74$ & Difference & \\
\hline $\begin{array}{l}\text { Children living with mother only, as } \\
\text { a proportion of children living with } \\
\text { mother only and two-parent families }\end{array}$ & & & & \\
\hline White & .191 & .095 & .096 & -.028 \\
\hline Black & .572 & .388 & .184 & .013 \\
\hline Hispanic & .278 & .253 & .025 & .036 \\
\hline $\begin{array}{l}\text { Children living with mother only: } \\
\text { proportion of mothers never married }\end{array}$ & .417 & .086 & .331 & .037 \\
\hline
\end{tabular}

Source: Actual trends: http://www.census.gov/population/www/docdemo/hh-fam.html\#ht, Tables CH1-CH5.

Notes: For Hispanics, the data series begins in 1980, so the simulation uses 1980-84 instead of 1970-74. 
Table 6: Simulated Effects of Contextual Variables on the Proportion of Childhood Spent with No Father for Alternative Specifications

\begin{tabular}{|c|c|c|c|c|c|c|}
\hline & 1 & 2 & 3 & 4 & 5 & 6 \\
\hline & $\begin{array}{l}\text { Base- } \\
\text { line }\end{array}$ & $\begin{array}{l}\text { No state } \\
\text { fixed effects }\end{array}$ & $\begin{array}{l}\text { No state or } \\
\text { division fixed } \\
\text { effects }\end{array}$ & $\begin{array}{l}1+\text { mother's age } \\
14 \text { family structure }\end{array}$ & $\begin{array}{l}4+\text { mother's } \\
\text { education }\end{array}$ & $\begin{array}{l}5+\text { mother's } \\
\text { AFQT score }\end{array}$ \\
\hline \multicolumn{7}{|c|}{ Female wage rate } \\
\hline White & .003 & .001 & .002 & .003 & .006 & .025 \\
\hline Black & .059 & .045 & .048 & .062 & .063 & .014 \\
\hline Hispanic & .052 & .058 & .058 & .049 & .067 & .022 \\
\hline \multicolumn{7}{|c|}{ Male wage rate } \\
\hline White & .007 & .006 & .004 & .007 & -.000 & -.012 \\
\hline Black & -.013 & -.016 & -.017 & -.014 & -.020 & .013 \\
\hline Hispanic & -.035 & -.042 & -.042 & -.035 & -.056 & -.025 \\
\hline \multicolumn{7}{|c|}{ Welfare Benefit } \\
\hline White & -.007 & .004 & .005 & -.007 & .001 & .005 \\
\hline Black & .005 & .031 & .025 & .005 & .014 & .009 \\
\hline Hispanic & -.011 & .006 & -.003 & -.015 & .000 & .008 \\
\hline \multicolumn{7}{|c|}{ Tax gain from marriage } \\
\hline White & .001 & .000 & .002 & .000 & .001 & -.001 \\
\hline Black & .007 & .005 & .006 & .006 & .001 & .002 \\
\hline Hispanic & .004 & .003 & .005 & -.001 & .002 & .001 \\
\hline \multicolumn{7}{|c|}{$\begin{array}{l}\text { Tax gain from a child if } \\
\text { married }\end{array}$} \\
\hline White & .015 & .016 & .016 & .015 & .005 & -.001 \\
\hline Black & .023 & .022 & .023 & .024 & .032 & .023 \\
\hline Hispanic & .021 & .021 & .021 & .018 & .015 & .006 \\
\hline \multicolumn{7}{|c|}{$\begin{array}{l}\text { Tax gain from a child if } \\
\text { single }\end{array}$} \\
\hline White & -.035 & -.036 & -.035 & -.032 & -.014 & -.001 \\
\hline Black & -.016 & -.013 & -.011 & -.021 & -.040 & -.029 \\
\hline Hispanic & -.030 & -.031 & -.031 & -.032 & -.036 & -.012 \\
\hline \multicolumn{7}{|c|}{ Welfare reform } \\
\hline White & .000 & -.002 & -.001 & -.001 & -.021 & -.021 \\
\hline Black & -.022 & -.001 & -.001 & -.015 & -.004 & -.008 \\
\hline Hispanic & -.014 & -.016 & -.012 & -.010 & -.027 & -.019 \\
\hline \multicolumn{7}{|c|}{ Unilateral divorce } \\
\hline White & .005 & .016 & .017 & .004 & .006 & .002 \\
\hline Black & -.049 & .009 & .007 & -.045 & -.021 & -.017 \\
\hline Hispanic & -.061 & -.026 & -.025 & -.040 & -.034 & -.005 \\
\hline
\end{tabular}

Notes: See the notes to Table 3 for a description of the simulations. The baseline simulations shown in the first column are from the same specification as those reported in the last column of Table 3. However, the simulated values differ slightly from the corresponding entries in Table 3 because the results reported here use the actual parameter estimates rather than 200 draws from the parameter distribution, as in Table 3. All specifications are the same as the baseline except for the difference noted in the column headers. 
Appendix Table A-1: Comparison of CPS and NLSY79

\begin{tabular}{|c|c|c|c|c|c|c|c|c|c|c|c|c|}
\hline \multicolumn{10}{|c|}{ A. Percent Distribution of Women by Union Status } & \multicolumn{3}{|c|}{ B. Mother's education } \\
\hline & \multicolumn{3}{|c|}{ White } & \multicolumn{3}{|c|}{ Black } & \multicolumn{3}{|c|}{ Hispanic } & & & \\
\hline 1995 & single & cohabiting & married & single & cohabiting & married & single & cohabiting & married & White & Black & Hispanic \\
\hline NLSY & 21.9 & 5.5 & 72.6 & 57.9 & 5.5 & 36.6 & 30.9 & 8.9 & 60.2 & 14.0 & 13.4 & 12.9 \\
\hline CPS & 20.2 & 4.0 & 75.8 & 53.9 & 3.5 & 42.6 & 23.9 & 2.1 & 74.0 & 13.9 & 13.3 & 11.7 \\
\hline \multicolumn{13}{|l|}{2004} \\
\hline NLSY & 22.3 & 4.8 & 72.9 & 58.9 & 4.7 & 36.3 & 32.3 & 6.4 & 61.2 & 14.0 & 13.4 & 12.9 \\
\hline CPS & 18.3 & 3.7 & 78.0 & 49.1 & 4.0 & 46.8 & 26.2 & 5.2 & 68.7 & 14.2 & 13.5 & 11.5 \\
\hline \multicolumn{10}{|c|}{ C. Number of own children under 18 in the mother's home } & \multicolumn{3}{|c|}{$\begin{array}{l}\text { D. Fraction of women with no } \\
\text { children at home }\end{array}$} \\
\hline 1995 & $0-5$ & $6-11$ & $12-17$ & $0-5$ & $6-11$ & $12-17$ & $0-5$ & 6-11 & $12-17$ & White & Black & Hispanic \\
\hline NLSY & 0.57 & 0.53 & 0.28 & 0.43 & 0.62 & 0.50 & 0.53 & 0.69 & 0.48 & 0.28 & 0.25 & 0.22 \\
\hline CPS & 0.54 & 0.64 & 0.37 & 0.42 & 0.70 & 0.57 & 0.65 & 0.79 & 0.57 & 0.25 & 0.24 & 0.16 \\
\hline \multicolumn{13}{|l|}{2004} \\
\hline NLSY & 0.12 & 0.40 & 0.62 & 0.08 & 0.25 & 0.55 & 0.12 & 0.36 & 0.65 & 0.36 & 0.46 & 0.34 \\
\hline CPS & 0.17 & 0.48 & 0.71 & 0.11 & 0.32 & 0.55 & 0.18 & 0.48 & 0.74 & 0.27 & 0.44 & 0.28 \\
\hline \multicolumn{10}{|c|}{ E. Distribution of children by mother's union status } & \multicolumn{3}{|c|}{$\begin{array}{l}\text { F. Fraction of children with no } \\
\text { father present }\end{array}$} \\
\hline 1995 & single & cohabiting & married & single & cohabiting & married & single & cohabiting & married & White & Black & Hispanic \\
\hline NLSY & 12.8 & 3.6 & 83.6 & 54.1 & 6.1 & 39.8 & 21.9 & 9.8 & 68.3 & 0.13 & 0.54 & 0.22 \\
\hline CPS & 16.1 & 2.7 & 81.2 & 53.0 & 2.6 & 44.3 & 23.8 & 1.3 & 74.9 & 0.14 & 0.56 & 0.25 \\
\hline \multicolumn{13}{|l|}{2004} \\
\hline NLSY & 13.9 & 2.5 & 83.6 & 49.2 & 5.0 & 45.7 & 13.3 & 6.4 & 70.3 & 0.14 & 0.49 & 0.23 \\
\hline CPS & 15.0 & 2.5 & 82.5 & 46.7 & 3.1 & 50.1 & 23.3 & 3.9 & 72.8 & 0.14 & 0.47 & 0.24 \\
\hline
\end{tabular}

Notes: The sample is aged30-38 in 1995 and 39-46 in 2004. 
Appendix Table A-2: Coefficient and Standard Error Estimates on Contextual Variables

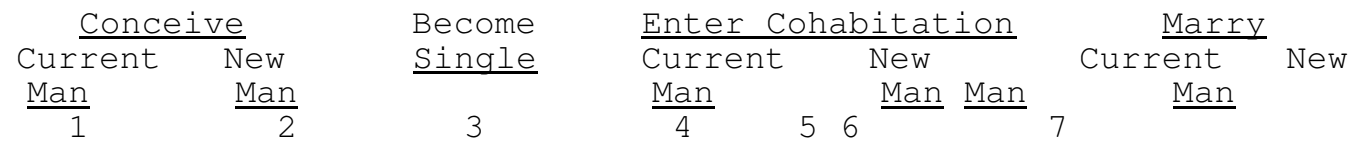

\begin{tabular}{|c|c|c|c|c|c|c|c|}
\hline elfare Ben. & $\begin{array}{c}-0.015 \\
(0.027)\end{array}$ & $\begin{array}{l}0.025 \\
(0.048)\end{array}$ & $\begin{array}{l}0.069 \\
(0.045)\end{array}$ & $\begin{array}{l}0.039 \\
(0.173)\end{array}$ & $\begin{array}{c}0.112 \\
(0.050)\end{array}$ & $\begin{array}{c}0.032 \\
(0.045)\end{array}$ & $\begin{array}{c}-0.069 \\
(0.041)\end{array}$ \\
\hline *Black & $\begin{array}{c}-0.035 \\
(0.030)\end{array}$ & $\begin{array}{l}0.000 \\
(0.043)\end{array}$ & $\begin{array}{l}0.022 \\
(0.042)\end{array}$ & $\begin{array}{c}0.258 \\
(0.131)\end{array}$ & $\begin{array}{c}-0.046 \\
(0.052)\end{array}$ & $\begin{array}{c}0.043 \\
(0.045)\end{array}$ & $\begin{array}{r}0.086 \\
(0.047)\end{array}$ \\
\hline *Hispanic & $\begin{array}{l}0.013 \\
(0.024)\end{array}$ & $\begin{array}{l}0.027 \\
(0.052)\end{array}$ & $\begin{array}{l}0.022 \\
(0.041)\end{array}$ & $\begin{array}{l}0.163 \\
(0.139)\end{array}$ & $\begin{array}{l}0.007 \\
(0.047)\end{array}$ & $\begin{array}{c}-0.048 \\
(0.044)\end{array}$ & $\begin{array}{r}0.09 \\
(\quad 0.04\end{array}$ \\
\hline Unil. Div. & $\begin{array}{l}0.107 \\
(0.164)\end{array}$ & $\begin{array}{c}-0.122 \\
(\quad 0.248)\end{array}$ & $\begin{array}{l}0.190 \\
(0.272)\end{array}$ & $\begin{array}{c}-0.036 \\
(0.822)\end{array}$ & $\begin{array}{l}0.089 \\
(0.258)\end{array}$ & $\begin{array}{l}0.135 \\
(0.271)\end{array}$ & $\begin{array}{r}-0.04 \\
(\quad 0.27\end{array}$ \\
\hline$\star B l a c k$ & $\begin{array}{c}-0.078 \\
(0.082)\end{array}$ & $\begin{array}{c}-0.041 \\
(0.140)\end{array}$ & $\begin{array}{c}-0.261 \\
\left(\begin{array}{c}0.115\end{array}\right)\end{array}$ & $\begin{array}{c}-0.033 \\
(0.431)\end{array}$ & $\begin{array}{c}-0.221 \\
\left(\begin{array}{c}0.137)\end{array}\right)\end{array}$ & $\begin{array}{c}-0.010 \\
\left(\begin{array}{c}0.133)\end{array}\right)\end{array}$ & $\begin{array}{r}0.29 \\
(\quad 0.14\end{array}$ \\
\hline *Hispanic & $\begin{array}{l}0.100 \\
(0.111)\end{array}$ & $\begin{array}{l}0.149 \\
(0.229)\end{array}$ & $\begin{array}{c}-0.543 \\
\left(\begin{array}{c}0.181)\end{array}\right)\end{array}$ & $\begin{array}{c}-0.043 \\
(0.640)\end{array}$ & $\begin{array}{c}0.035 \\
(0.193)\end{array}$ & $\begin{array}{c}0.457 \\
(0.235)\end{array}$ & $\begin{array}{r}-0.0 \\
(\quad 0.2\end{array}$ \\
\hline Welfare Ref. & $\begin{array}{l}0.090 \\
(0.093)\end{array}$ & $\begin{array}{l}0.409 \\
(0.345)\end{array}$ & $\begin{array}{l}0.002 \\
(\quad 0.134)\end{array}$ & $\begin{array}{l}0.392 \\
(0.622)\end{array}$ & $\begin{array}{c}-0.100 \\
(0.171)\end{array}$ & $\begin{array}{l}0.242 \\
(0.168)\end{array}$ & $\begin{array}{r}0.03 \\
(\quad 0.20\end{array}$ \\
\hline$\star B l a c k$ & $\begin{array}{c}-0.261 \\
(\quad 0.125)\end{array}$ & $\begin{array}{c}-0.605 \\
(0.332)\end{array}$ & $\begin{array}{c}0.094 \\
(\quad 0.148)\end{array}$ & $\begin{array}{c}0.079 \\
(\quad 0.587)\end{array}$ & $\begin{array}{c}-0.056 \\
(\quad 0.177)\end{array}$ & $\begin{array}{c}0.111 \\
(0.188)\end{array}$ & 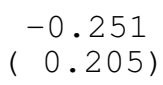 \\
\hline *Hispanic & $\begin{array}{r}-0.016 \\
(\quad 0.115)\end{array}$ & $\begin{array}{c}-0.136 \\
(0.399)\end{array}$ & $\begin{array}{l}0.051 \\
(\quad 0.154)\end{array}$ & $\begin{array}{c}-0.004 \\
(\quad 0.724)\end{array}$ & $\begin{array}{l}0.261 \\
(\quad 0.212)\end{array}$ & $\begin{array}{l}0.092 \\
(\quad 0.219)\end{array}$ & $\begin{array}{r}0.2 \\
(\quad 0.2\end{array}$ \\
\hline Male Wage & $\begin{array}{c}-0.136 \\
(0.051)\end{array}$ & $\begin{array}{l}0.044 \\
(0.103)\end{array}$ & $\begin{array}{c}0.032 \\
(0.086)\end{array}$ & $\begin{array}{l}0.287 \\
(0.281)\end{array}$ & $\begin{array}{l}0.029 \\
(0.089)\end{array}$ & $\begin{array}{c}-0.050 \\
(\quad 0.091)\end{array}$ & $\begin{array}{r}0.0 \\
(\quad 0.0\end{array}$ \\
\hline$\star B l a c k$ & $\begin{array}{l}0.200 \\
(0.061)\end{array}$ & $\begin{array}{c}0.022 \\
(0.101)\end{array}$ & $\begin{array}{c}-0.074 \\
(\quad 0.100)\end{array}$ & $\begin{array}{l}0.033 \\
(\quad 0.290)\end{array}$ & $\begin{array}{c}0.008 \\
(\quad 0.104)\end{array}$ & $\begin{array}{c}-0.110 \\
(\quad 0.106)\end{array}$ & $\begin{array}{r}-0.07 \\
(\quad 0.10\end{array}$ \\
\hline *Hispanic & $\begin{array}{l}0.187 \\
(0.054)\end{array}$ & 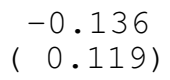 & $\begin{array}{c}-0.160 \\
\left(\begin{array}{l}0.107)\end{array}\right)\end{array}$ & $\begin{array}{c}-0.050 \\
\left(\begin{array}{l}0.308)\end{array}\right)\end{array}$ & $\begin{array}{l}0.100 \\
(0.116)\end{array}$ & $\begin{array}{r}0.218 \\
(\quad 0.107)\end{array}$ & $\begin{array}{r}-0.0 \\
\left(\begin{array}{l}0.0\end{array}\right.\end{array}$ \\
\hline Female Wage & $\begin{array}{l}0.127 \\
(0.065)\end{array}$ & $\begin{array}{c}-0.060 \\
(0.153)\end{array}$ & $\begin{array}{l}0.045 \\
(0.108)\end{array}$ & $\begin{array}{c}-0.459 \\
(0.374)\end{array}$ & $\begin{array}{c}-0.112 \\
(\quad 0.115)\end{array}$ & $\begin{array}{c}-0.008 \\
(0.110)\end{array}$ & $\begin{array}{r}0.00 \\
(\quad 0.10\end{array}$ \\
\hline$\star B l a c k$ & $\begin{array}{c}-0.200 \\
(0.086)\end{array}$ & $\begin{array}{l}0.020 \\
(\quad 0.165)\end{array}$ & $\begin{array}{l}0.126 \\
(0.139)\end{array}$ & $\begin{array}{c}-0.146 \\
\left(\begin{array}{l}0.449)\end{array}\right)\end{array}$ & $\begin{array}{c}-0.037 \\
\left(\begin{array}{l}0.149)\end{array}\right)\end{array}$ & $\begin{array}{l}0.064 \\
(0.143)\end{array}$ & $\begin{array}{r}-0.09 \\
(\quad 0.15\end{array}$ \\
\hline *Hispanic & $\begin{array}{c}-0.188 \\
(0.095)\end{array}$ & $\begin{array}{c}0.278 \\
(0.199)\end{array}$ & $\begin{array}{c}0.181 \\
(0.163)\end{array}$ & $\begin{array}{l}0.044 \\
(0.474)\end{array}$ & $\begin{array}{c}-0.029 \\
(\quad 0.193)\end{array}$ & $\begin{array}{l}0.073 \\
(0.183)\end{array}$ & $\begin{array}{r}-0.09 \\
(\quad 0.15\end{array}$ \\
\hline Tax Rate & $\begin{array}{c}-0.322 \\
(\quad 0.492)\end{array}$ & $\begin{array}{l}0.664 \\
(1.115)\end{array}$ & $\begin{array}{l}2.846 \\
(\quad 0.884)\end{array}$ & $\begin{array}{c}0.000 \\
(0.000)\end{array}$ & $\begin{array}{c}0.000 \\
(0.000)\end{array}$ & $\begin{array}{c}-0.641 \\
\left(\begin{array}{c}1.036)\end{array}\right)\end{array}$ & $\begin{array}{r}1.13 \\
(\quad 1.24\end{array}$ \\
\hline$\star B l a c k$ & $\begin{array}{l}1.238 \\
(0.735)\end{array}$ & $\begin{array}{c}-2.000 \\
(\quad 1.225)\end{array}$ & 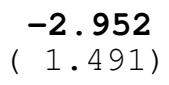 & $\begin{array}{c}0.000 \\
(0.000)\end{array}$ & $\begin{array}{c}0.000 \\
(0.000)\end{array}$ & $\begin{array}{c}2.189 \\
(1.401)\end{array}$ & $\begin{array}{r}0.0 \\
(\quad 1.5\end{array}$ \\
\hline *Hispanic & $\begin{array}{c}-0.337 \\
(\quad 0.864)\end{array}$ & $\begin{array}{c}-1.482 \\
\left(\begin{array}{c}1.678)\end{array}\right)\end{array}$ & $\begin{array}{c}-1.183 \\
(1.500)\end{array}$ & $\begin{array}{l}0.000 \\
(0.000)\end{array}$ & $\begin{array}{l}0.000 \\
(0.000)\end{array}$ & $\begin{array}{l}1.490 \\
(1.791)\end{array}$ & $\begin{array}{l}1 . \\
1 .\end{array}$ \\
\hline
\end{tabular}

Notes: Welfare benefit is in units of 100 dollars per month. Standard errors are in parentheses. Coefficient estimates that are significantly different from zero at the $10 \%$ level are in bold. 
Appendix Table A-3: Coefficient and Standard Error Estimates on Individual Variables

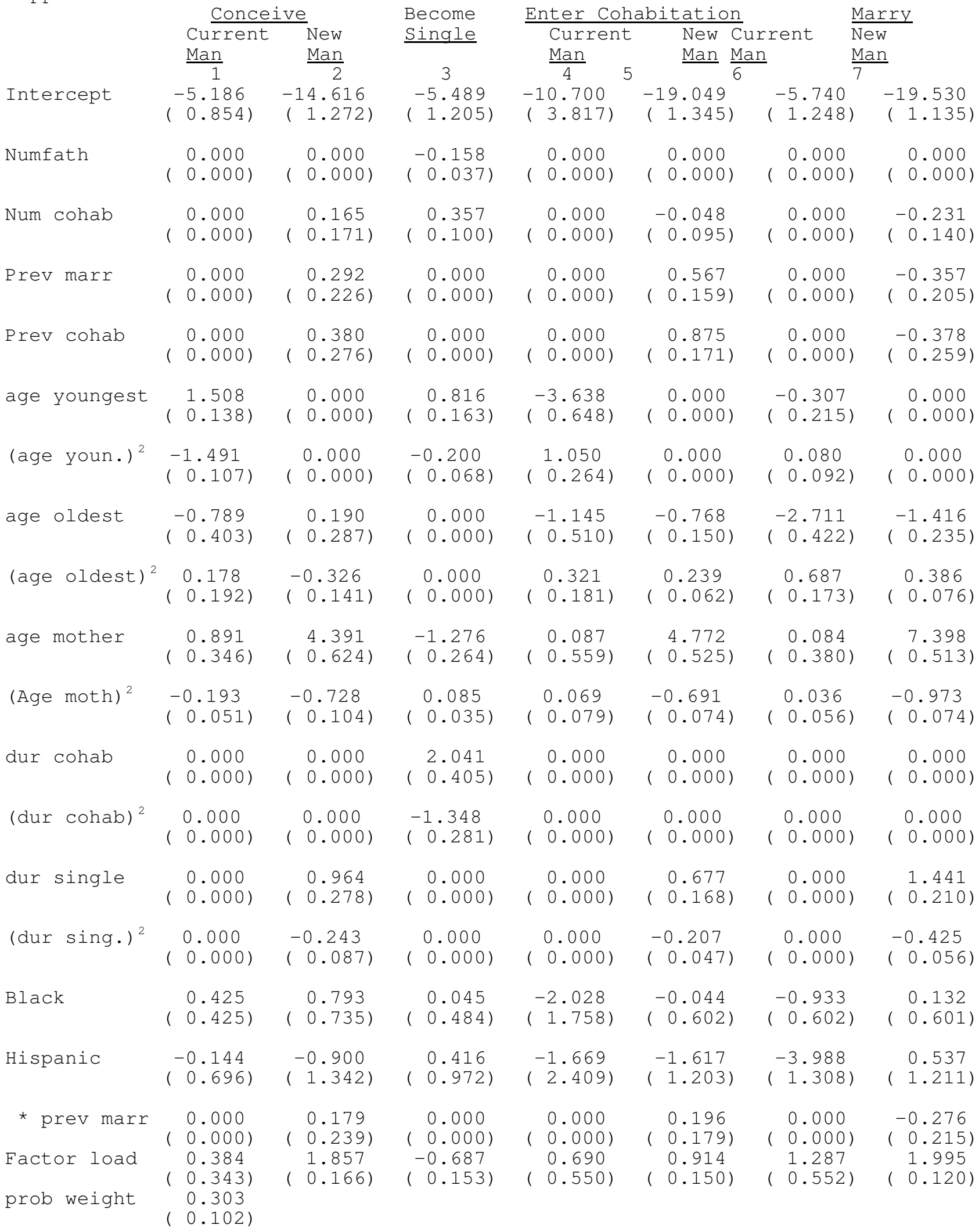

Notes: Numfath $=$ Number of the mother's children fathered by the current man. Num cohab = number of previous cohabitations. Prev marr = Married in previous spell (currently single). prev cohab = Cohabited in previous spell (currently single). age youngest = age of youngest child in months/100. age oldest = age of oldest child in months/100. age mother = age of mother in months/100. dur cohab = duration of current cohabitation in months/100. dur single = duration of current single spell in months/100. Factor load = coefficient on the random effect. prob weight = logit of estimated probability weight (log[pw/(1-pw)]). Coefficient estimates on state dummies, division dummies, period dummies, year dummies, and time trends are not shown. 
Appendix Table A-4: Comparison of Baseline Simulation Outcomes with Actual Outcomes

\begin{tabular}{|c|c|c|c|c|c|c|}
\hline & \multicolumn{2}{|c|}{ White } & \multicolumn{2}{|c|}{ Black } & \multicolumn{2}{|c|}{ Hispanic } \\
\hline & Actual & $\begin{array}{l}\text { Simul- } \\
\text { ated }\end{array}$ & Actual & $\begin{array}{l}\text { Simul- } \\
\text { ated }\end{array}$ & Actual & $\begin{array}{l}\text { Simul- } \\
\text { ated }\end{array}$ \\
\hline \multicolumn{7}{|l|}{ Mother } \\
\hline Number of children born & 1.71 & 2.04 & 1.89 & 2.42 & 1.99 & 2.13 \\
\hline No children & .21 & .21 & .18 & .21 & .17 & .26 \\
\hline Ever cohabited & .43 & .32 & .36 & .32 & .39 & .24 \\
\hline Ever married & .89 & .87 & .62 & .74 & .82 & .78 \\
\hline Marital status at first birth: single & .11 & .05 & .66 & .52 & .26 & .13 \\
\hline Cohabiting & .03 & .03 & .04 & .04 & .06 & .04 \\
\hline Married & .85 & .92 & .29 & .45 & .68 & .83 \\
\hline Age at first birth & 25.2 & 24.1 & 21.8 & 21.7 & 23.3 & 22.7 \\
\hline \multicolumn{7}{|l|}{ Child } \\
\hline Mother was single at conception & .16 & .11 & .64 & .53 & .27 & .18 \\
\hline Mother was single at birth & .08 & .03 & .59 & .44 & .20 & .10 \\
\hline Ever live with no father & .31 & .19 & .76 & .61 & .45 & .28 \\
\hline \multicolumn{7}{|l|}{ Proportion of childhood lived with: } \\
\hline No father & .12 & .07 & .55 & .33 & .22 & .12 \\
\hline Married biological father & .77 & .87 & .33 & .48 & .65 & .79 \\
\hline Cohabiting biological father & .01 & .00 & .02 & .01 & .03 & .01 \\
\hline Married step father & .06 & .05 & .07 & .16 & .07 & .07 \\
\hline Cohabiting step father & .02 & .01 & .03 & .02 & .03 & .01 \\
\hline \multicolumn{7}{|l|}{$\begin{array}{l}\text { Ever experience the following event, } \\
\text { conditional on being at risk: }\end{array}$} \\
\hline Biological father enters household & .27 & .08 & .18 & .12 & .24 & .11 \\
\hline Biological father leaves household & .25 & .16 & .45 & .31 & .31 & .21 \\
\hline Step father enters household & .53 & .59 & .36 & .60 & .51 & .61 \\
\hline Step father leaves household & .38 & .21 & .52 & .33 & .39 & .25 \\
\hline
\end{tabular}

Notes: All entries are means. Actual observations are weighted by the inverse of the number of distinct event histories per woman. 
Appendix Table A-5: Comparison of baseline simulated monthly child transition probabilities $(* 100)$ among different family structures with actual rates

\begin{tabular}{|c|c|c|c|c|c|c|}
\hline \multirow{2}{*}{$\begin{array}{l}\text { All ages } \\
\text { No father to: }\end{array}$} & \multicolumn{2}{|c|}{ White } & \multicolumn{2}{|c|}{ Black } & \multicolumn{2}{|c|}{ Hispanic } \\
\hline & Actual & Simulated & Actual & Simulated & Actual & Simulated \\
\hline 1. cohabiting biological father & 0.04 & 0.02 & 0.05 & 0.04 & 0.08 & 0.04 \\
\hline 2. Cohabiting step father & 0.60 & 0.59 & 0.21 & 0.34 & 0.48 & 0.54 \\
\hline 3. Married biological father & 0.07 & 0.04 & 0.06 & 0.05 & 0.05 & 0.04 \\
\hline 4. Married step father & 0.36 & 0.39 & 0.13 & 0.37 & 0.26 & 0.39 \\
\hline \multicolumn{7}{|l|}{ Cohabiting biological father to: } \\
\hline 5. No father & 0.75 & 1.12 & 1.18 & 1.24 & 0.79 & 1.13 \\
\hline 6. Married biological father & 1.64 & 1.98 & 1.71 & 3.17 & 1.24 & 2.05 \\
\hline \multicolumn{7}{|l|}{ Cohabiting step father to: } \\
\hline 7. No father & 1.06 & 1.09 & 1.23 & 1.11 & 0.90 & 1.04 \\
\hline 8. Married step father & 2.84 & 6.33 & 2.39 & 6.40 & 1.96 & 4.72 \\
\hline \multicolumn{7}{|l|}{ Married biological father to: } \\
\hline 9. No father & 0.19 & 0.11 & 0.74 & 0.23 & 0.40 & 0.14 \\
\hline \multicolumn{7}{|l|}{ Cohabiting biological father to: } \\
\hline 10. No father & 0.35 & 0.16 & 0.24 & 0.27 & 0.23 & 0.18 \\
\hline \multicolumn{7}{|l|}{ Ages $0-5$} \\
\hline No father to: & Actual & Simulated & Actual & Simulated & Actual & Simulated \\
\hline 11. cohabiting biological father & 0.12 & 0.06 & 0.11 & 0.08 & 0.18 & 0.10 \\
\hline 12. Cohabiting step father & 0.64 & 0.67 & 0.19 & 0.32 & 0.44 & 0.56 \\
\hline 13. Married biological father & 0.20 & 0.11 & 0.14 & 0.11 & 0.20 & 0.10 \\
\hline 14. Married step father & 0.38 & 0.49 & 0.11 & 0.41 & 0.24 & 0.43 \\
\hline \multicolumn{7}{|l|}{ Cohabiting biological father to: } \\
\hline 15. No father & 0.81 & 1.20 & 1.16 & 1.27 & 1.01 & 1.20 \\
\hline 16. Married biological father & 1.80 & 2.30 & 1.68 & 3.63 & 1.39 & 2.43 \\
\hline \multicolumn{7}{|l|}{ Cohabiting step father to: } \\
\hline 17. No father & 1.45 & 0.97 & 1.09 & 1.06 & 0.81 & 0.97 \\
\hline 18. Married step father & 3.49 & 7.88 & 2.26 & 7.42 & 1.83 & 5.69 \\
\hline \multicolumn{7}{|l|}{ Married biological father to: } \\
\hline 19. No father & 0.42 & 0.14 & 1.08 & 0.28 & 0.57 & 0.17 \\
\hline \multicolumn{7}{|l|}{ Cohabiting biological father to: } \\
\hline 20. No father & 0.21 & 0.19 & 0.27 & 0.36 & 0.25 & 0.22 \\
\hline
\end{tabular}



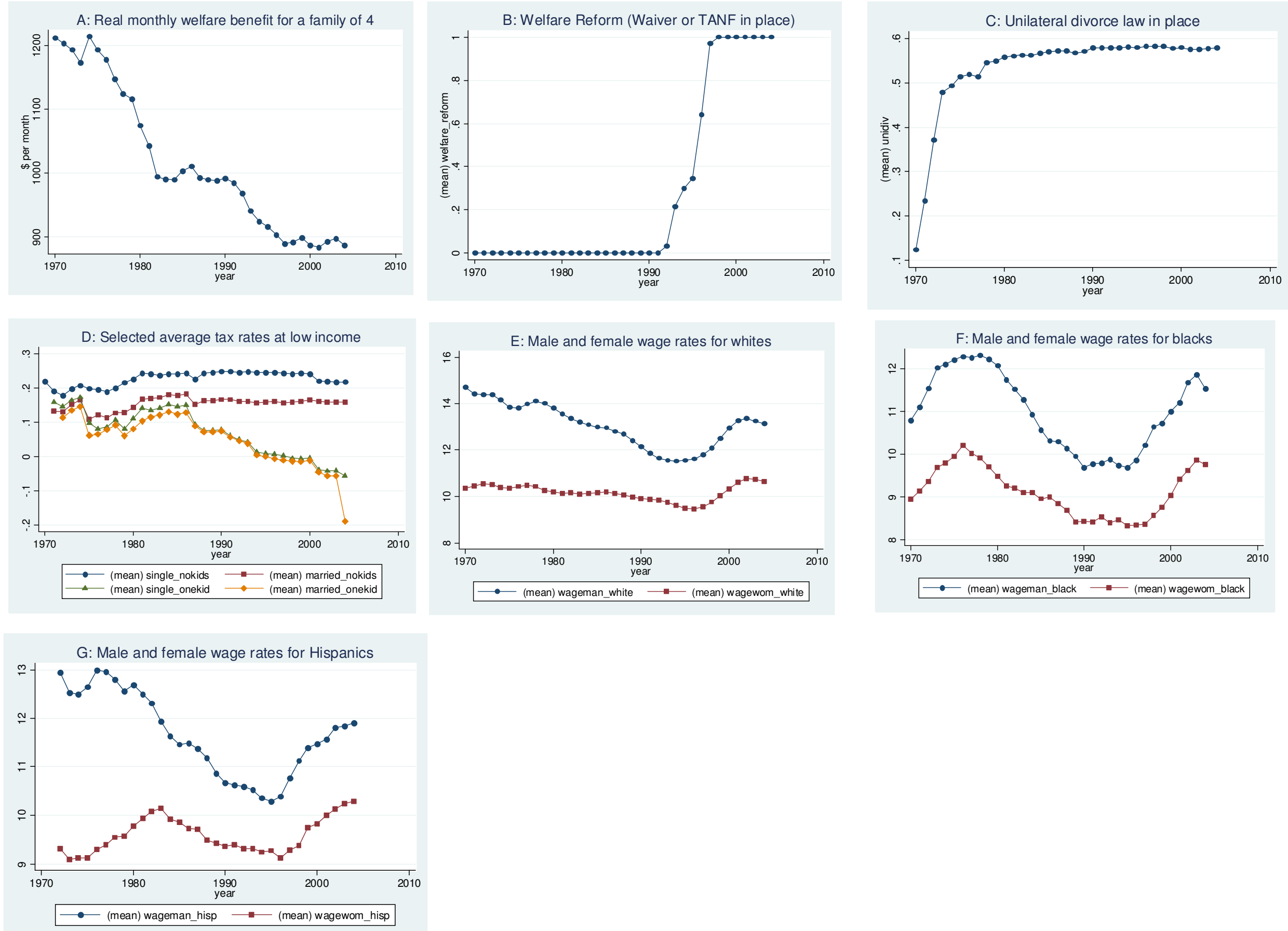

Figure 1: Aggregate Trends in Contextual Variables 

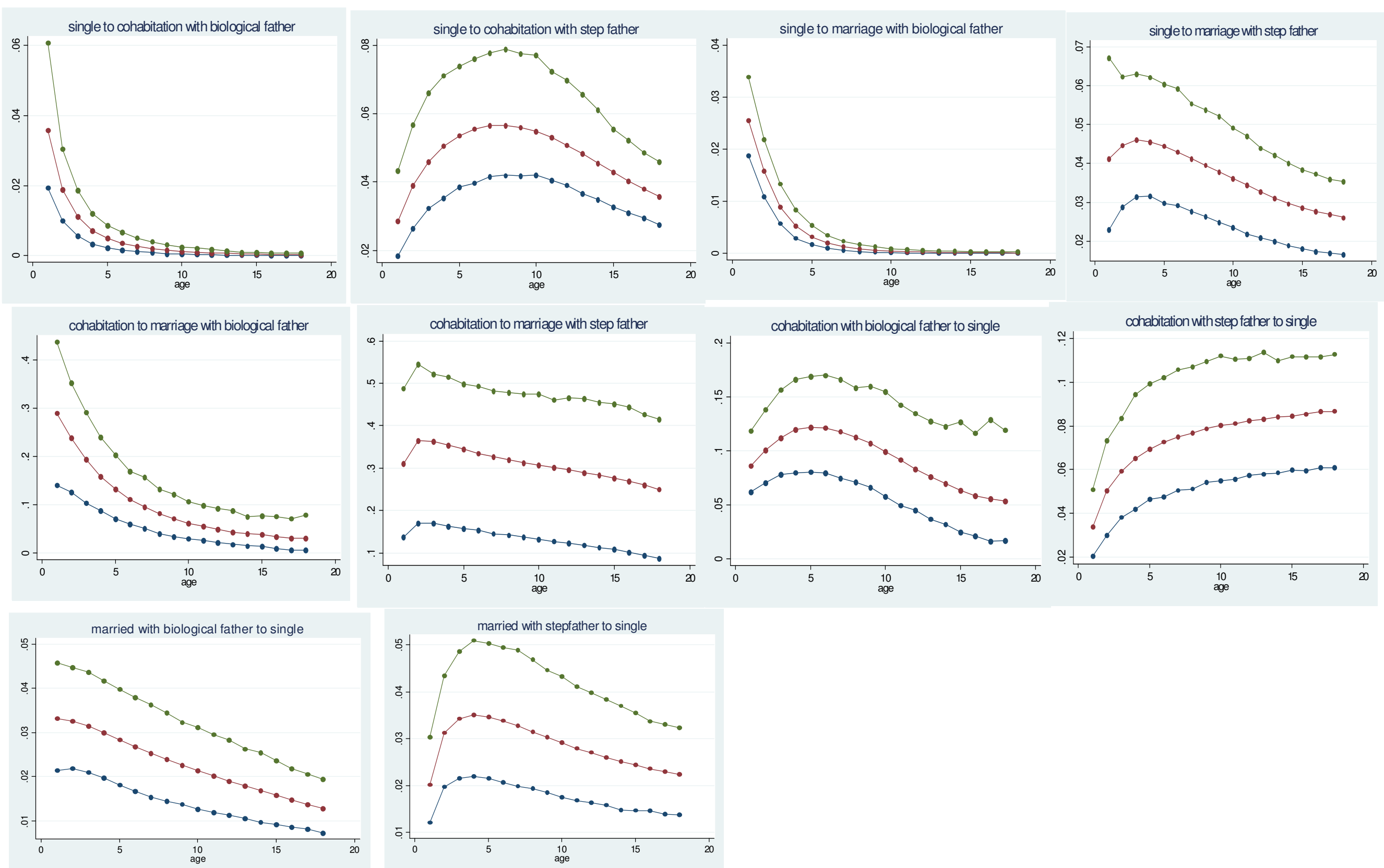

Figure 2: Simulated effect of a one standard deviation increase in the female wage rate on annual family structure transitions of children of black mothers

Notes: The middle line (in red) in each panel is the mean estimate over the 200 draws from the parameter distribution. The other lines are the upper and lower limits of the 95 percent confidence interval. 